\title{
Carbonate mineral saturation states in the East China Sea: present conditions and future scenarios
}

\author{
W.-C. Chou ${ }^{1}$, G.-C. Gong ${ }^{1,2,3}$, C.-C. Hung ${ }^{4}$, and Y.-H. Wu ${ }^{1}$ \\ ${ }^{1}$ Institute of Marine Environmental Chemistry and Ecology, National Taiwan Ocean University, Keelung 202, Taiwan \\ ${ }^{2}$ Center of Excellence for the Oceans, National Taiwan Ocean University, Keelung 202, Taiwan \\ ${ }^{3}$ Taiwan Ocean Research Institute, National Applied Research Laboratories, Kaohsiung 852, Taiwan \\ ${ }^{4}$ Institute of Marine Geology and Chemistry, National Sun Yet-Sen University, Kaohsiung 804, Taiwan
}

Correspondence to: W.-C. Chou (wcchou@mail.ntou.edu.tw)

Received: 20 February 2013 - Published in Biogeosciences Discuss.: 21 March 2013

Revised: 27 August 2013 - Accepted: 2 September 2013 - Published: 11 October 2013

\begin{abstract}
To assess the impact of rising atmospheric $\mathrm{CO}_{2}$ and eutrophication on the carbonate chemistry of the East China Sea shelf waters, saturation states $(\Omega)$ for two important biologically relevant carbonate minerals - calcite $\left(\Omega_{\mathrm{c}}\right)$ and aragonite $\left(\Omega_{\mathrm{a}}\right)$ - were calculated throughout the water column from dissolved inorganic carbon (DIC) and total alkalinity (TA) data collected in spring and summer of 2009. Results show that the highest $\Omega_{\mathrm{c}}(\sim 9.0)$ and $\Omega_{\mathrm{a}}(\sim 5.8)$ values were found in surface water of the Changjiang plume area in summer, whereas the lowest values $\left(\Omega_{\mathrm{c}}=\sim 2.7\right.$ and $\Omega_{\mathrm{a}}=\sim 1.7$ ) were concurrently observed in the bottom water of the same area. This divergent behavior of saturation states in surface and bottom waters was driven by intensive biological production and strong stratification of the water column. The high rate of phytoplankton production, stimulated by the enormous nutrient discharge from the Changjiang, acts to decrease the ratio of DIC to TA, and thereby increases $\Omega$ values. In contrast, remineralization of organic matter in the bottom water acts to increase the DIC to TA ratio, and thus decreases $\Omega$ values. The projected result shows that continued increases of atmospheric $\mathrm{CO}_{2}$ under the IS92a emission scenario will decrease $\Omega$ values by $40-50 \%$ by the end of this century, but both the surface and bottom waters will remain supersaturated with respect to calcite and aragonite. Nevertheless, superimposed on such $\Omega$ decrease is the increasing eutrophication, which would mitigate or enhance the $\Omega$ decline caused by anthropogenic $\mathrm{CO}_{2}$ uptake in surface and bottom waters, respectively. Our simulation reveals that, under the combined impact of eutrophication and augmentation of atmospheric $\mathrm{CO}_{2}$, the bottom water of the Changjiang plume area will be-
\end{abstract}

come undersaturated with respect to aragonite $\left(\Omega_{\mathrm{a}}=\sim 0.8\right)$ by the end of this century, which would threaten the health of the benthic ecosystem.

\section{Introduction}

Since the beginning of the industrial revolution, human activities have released more than 400 billion tons of carbon into the atmosphere through fossil fuel combustion, cement production and land-use change (Sabine et al., 2004a). Between 1959 and 2008 , only about $43 \%$ of the $\mathrm{CO}_{2}$ released by human activity accumulated in the atmosphere; the remainder was absorbed by carbon sinks on land and in the oceans (Le Quéré et al., 2009). It is estimated that the oceans have taken up 118 billion tons of carbon since 1800 (i.e., approximate one-third of $\mathrm{CO}_{2}$ emitted from human activities), which has tempered the rise in atmospheric $\mathrm{CO}_{2}$ level by about $55 \%$, and thereby has mitigated climate-change impacts (Sabine et al., 2004b). Oceanic $\mathrm{CO}_{2}$ uptake, however, is not benign; it is causing a series of changes in ocean water chemistry (Caldeira and Wickett, 2005; Feely et al., 2009), and those changes will affect a range of biological processes in marine organisms (Fabry et al., 2008; Doney et al., 2009).

The inorganic carbon system is one of the most important chemical equilibria in the ocean and is largely responsible for controlling the $\mathrm{pH}$ of seawater through a series of wellknown reactions (Zeebe and Wolf-Gladrow, 2001). Once dissolved in seawater, aqueous $\mathrm{CO}_{2}\left(\mathrm{CO}_{2}(\mathrm{aq})\right)$ reacts with water to form carbonic acid $\left(\mathrm{H}_{2} \mathrm{CO}_{3}\right)$ : 
$\mathrm{CO}_{2(\mathrm{aq})}+\mathrm{H}_{2} \mathrm{O} \rightarrow \mathrm{H}_{2} \mathrm{CO}_{3}$.

Carbonic acid can then dissociate by losing hydrogen ions to form bicarbonate ions $\left(\mathrm{HCO}_{3}^{-}\right)$:

$$
\mathrm{H}_{2} \mathrm{CO}_{3} \rightarrow \mathrm{H}^{+}+\mathrm{HCO}_{3}^{-} \text {. }
$$

At the current ocean $\mathrm{pH}$ level, a large fraction of the additional hydrogen ions are buffered by combining with carbonate ion $\left(\mathrm{CO}_{3}^{2-}\right)$ to form bicarbonate:

$\mathrm{H}^{+}+\mathrm{CO}_{3}^{2-} \rightarrow \mathrm{HCO}_{3}^{-}$.

Consequently, the overall reaction of dissolving $\mathrm{CO}_{2}$ in seawater results in an increase in concentrations of $\mathrm{CO}_{2}^{*}$ (i.e., the sum of $\left.\mathrm{CO}_{2(\mathrm{aq})}+\mathrm{H}_{2} \mathrm{CO}_{3}\right), \mathrm{HCO}_{3}^{-}$and $\mathrm{H}^{+}$, and a decrease in $\mathrm{CO}_{3}^{2-}$ concentration and $\mathrm{pH}$. The entire process is commonly referred to as "ocean acidification".

The decline of $\mathrm{CO}_{3}^{2-}$ concentration induced by ocean acidification has a corresponding effect on the carbonate saturation state of seawater, which is expressed by $\Omega$ :

$\Omega=\frac{\left[\mathrm{Ca}^{2+}\right] \mathrm{sw} \times\left[\mathrm{CO}_{3}^{2-}\right] \mathrm{sw}}{K_{\mathrm{sp}}^{*}}$,

where $\left[\mathrm{Ca}^{2+}\right] \mathrm{sw}$ and $\left[\mathrm{CO}_{3}^{2-}\right] \mathrm{sw}$ are the concentrations of $\mathrm{Ca}^{2+}$ and $\mathrm{CO}_{3}^{2-}$ in seawater, respectively, and $K_{\mathrm{sp}}^{*}$ is the solubility product of a particular carbonate mineral (e.g., aragonite and calcite) at the in situ temperature, salinity, and pressure. By definition, $\Omega=1$ signifies seawater is in equilibrium with that mineral; $\Omega>1$ reflects supersaturation favoring precipitation; and $\Omega<1$ corresponds to undersaturation favoring dissolution. Since preindustrial times, the saturation states of aragonite and calcite have declined approximately by $16 \%$, and they are expected to decrease a further $50 \%$ if atmospheric $\mathrm{CO}_{2}$ concentrations reach 780 ppmv near the end of this century (Feely et al., 2004 and 2009; Orr et al., 2005). Reduction in saturation states has been experimentally determined to be unfavorable for most calcifying organisms, including coccolithophores, foraminifera, mussels, urchins, oysters, corals, and coralline algae, to form their shells, skeletons and other protective structures (Gattuso et al., 1998; Kleypas et al., 1999; Fabry et al., 2008; Ries et al., 2009; Kroeker et al., 2010). Changes in calcification are likely to constitute a major negative effect on marine biota, and this process is so far the best-documented and most widely observed biological effect of ocean acidification.

Previous model projections indicate that the high-latitude oceans are most susceptible to ocean acidification (Orr et al., 2005; Fabry et al., 2009; Feely et al., 2009), because cold temperatures facilitate $\mathrm{CO}_{2}$ dissolution and thus precondition the seawater in high-latitude regions to have lower saturation states of calcium carbonate compared to temperate and tropical regions. Nevertheless, recent studies show that the coastal ocean is experiencing multiple environmental stressors that may act synergistically to exacerbate acidification (Doney, 2010). For instance, it has been suggested that eutrophication, rather than acidification induced by anthropogenic $\mathrm{CO}_{2}$ uptake, may have dictated $\mathrm{pH}$ changes in coastal oceans (Borges and Gypens, 2010; Provoost et al., 2010). Recently, Cai et al. (2011) further showed that anthropogenic $\mathrm{CO}_{2}$ invasion and eutrophication have acted in concert to lower the hypoxic bottom water $\mathrm{pH}$ and carbonate saturation state greatly on the continental shelf impacted by the nutrient-laden Mississippi River. They also found that the combined effect is greater than the simple addition of each, due to a synergism between respiratory and fossilfuel-derived $\mathrm{CO}_{2}$, which reduces seawater buffering capacity. Furthermore, atmospheric nitrogen and sulfur deposition may also aggravate acidification in coastal waters (Doney et al., 2007). Therefore, the coastal ocean, which is subject to the strong influence of multiple environmental stressors, may represent one of the systems most vulnerable to the potential negative effects of ocean acidification. More importantly, because coastal oceans are some of the most productive marine ecosystems that sustain numerous commercially valuable fisheries (e.g., those for shellfish and crustaceans), it is critical to gain a better understanding on how multiple environmental stressors would affect acidification in the coastal ocean.

The subtropical East China Sea (ECS), located off the southeast coast of China, is one of the largest marginal seas in the northwest Pacific. The Changjiang (Yangtze River) is the longest river in Asia and the third longest in the world. It flows through densely populated areas with intensive agriculture and industrial activities, and then empties into the northwestern part of the ECS with an enormous water discharge of $9 \times 10^{11} \mathrm{~m}^{3} \mathrm{yr}^{-1}$, which accounts for $90-95 \%$ of the total riverine input to the ECS (Chen et al., 2001). The materials carried by the Changjiang runoff thus greatly influence the marine environment of the ECS (Zhang et al., 2007). Due to the rapid development of industry and increased agricultural production associated with the growth of the Chinese population, the export of dissolved inorganic $\mathrm{N}$ from the Changjiang increased threefold between 1970 and 2003 (Yan et al., 2010). This is ten times faster than the increase of total global river export over the period 1970-2000 (35\%; Seitzinger et al., 2010). Therefore, the ECS may represent one of the areas most impacted by worsening eutrophication worldwide over recent decades. Some recent studies have shown that the elevated nutrient discharge had led to some ecological consequences (e.g., harmful algal blooms and hypoxic events; Li et al., 2007; Rabouille et al., 2008), and might have altered biogeochemical cycles in the ECS (Chou et al., 2013). Nonetheless, how eutrophication would act together with anthropogenic $\mathrm{CO}_{2}$ invasion to impact carbonate 
mineral saturation states in the ECS has not been investigated to date.

In this study we first describe the seasonal variability of the seawater carbonate system over the ECS shelf in spring and summer of 2009, and then we investigate the role of riverine runoff on regulating carbonate mineral saturation states. Finally, future scenarios of the saturation states are explored in the context of the combined impact of eutrophication and augmentation of atmospheric $\mathrm{CO}_{2}$.

\section{Materials and methods}

\subsection{Sampling and analytical methods}

Seawater sampling was conducted aboard the R/V Ocean Researcher I during spring (from 29 April to 12 May) and summer (from 29 June to 13 July) cruises on the ECS shelf (refer to Fig. 1 for sampling locations) in 2009 as part of the Long-term Observation and Research of the East China Sea program (LORECS), which is closely related to two large international cooperative projects: the Surface Ocean Lower Atmosphere Study (SOLAS) and the International Biogeochemical and Ecosystem Research (IMBER) Project. Note that one more northern transect was investigated during the summer cruise (the $\mathrm{H}$ transect in Fig. 1) to cover the influence of the Changjiang discharge better, which reaches maximum in summer. At each hydrographic station, seawater samples were collected at six water depths (intervals of 3-25 m, depending on the bottom depth), using Go-Flo bottles mounted onto a rosette assembly. Water samples collected at $2 \mathrm{~m}$ depth represented surface waters. Depth profiles of temperature and salinity were recorded using a Seabird SBE9/11-plus conductivity-temperature-depth (CTD) system.

Discrete water samples for dissolved inorganic carbon (DIC) and total alkalinity (TA) analysis were drawn from Go-Flo bottles into $350 \mathrm{~mL}$ pre-cleaned borosilicate bottles. These samples were subsequently poisoned with $200 \mu \mathrm{L}$ of $\mathrm{HgCl}_{2}$-saturated solution to halt biological activity, sealed, and returned to the laboratory. DIC samples were analyzed using a DIC analyzer (AS-C3, Apollo SciTech Inc., Georgia, USA) with a precision of $0.2 \%$ (Cai and Wang, 1998). Seawater samples of $0.75 \mathrm{~mL}$ were acidified by addition of $0.5 \mathrm{~mL} 10 \% \mathrm{H}_{3} \mathrm{PO}_{4}$. The extracted $\mathrm{CO}_{2}$ gas was subsequently measured using a nondispersive infrared $\mathrm{CO}_{2}$ detector (Li-COR, LI-7000). TA was measured by Gran titration of a $20 \mathrm{~mL}$ seawater sample with $0.1 \mathrm{~N} \mathrm{HCl}$ in an open-cell setting (Cai et al., 2010). Each sample was titrated at least twice with a precision of $0.1 \%$. Certified reference material provided by A. G. Dickson (Scripps Institution of Oceanography) was used throughout this study for calibration and accuracy assessments for both DIC and TA measurements.

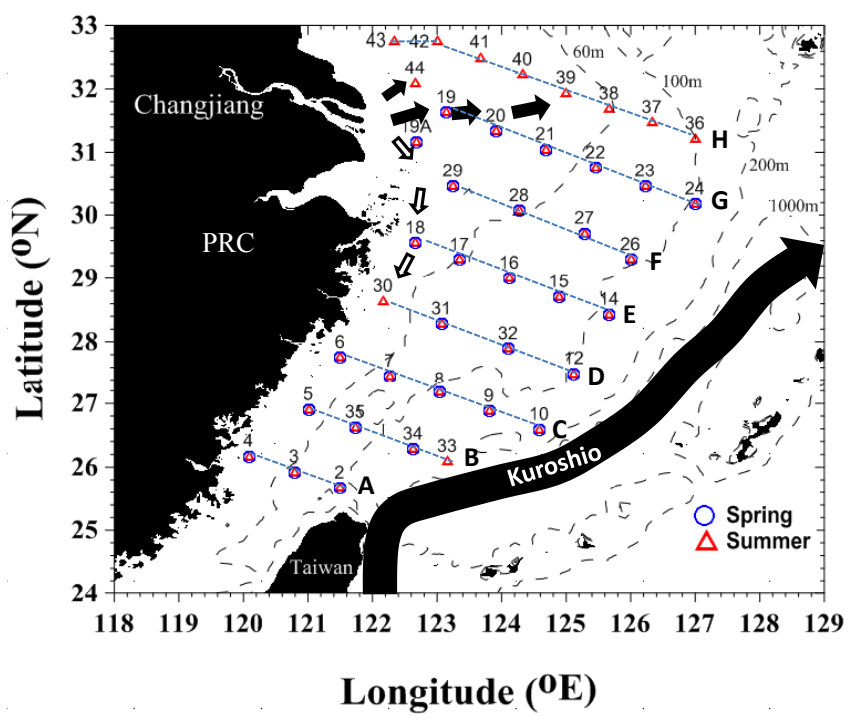

Fig. 1. Bathymetric map showing the sampling stations during the cruises in spring (circles) and summer (triangles) of 2009. Superimposed is a schematic representation of the Kuroshio Current and the seasonal dispersion of the Changjiang discharge, in which empty and solid arrows represent the conditions during dry and flood seasons, respectively.

\subsection{Calculation of carbonate mineral saturation states}

Seawater $\mathrm{pH}$ and saturation states for calcite $\left(\Omega_{\mathrm{c}}\right)$ and aragonite $\left(\Omega_{\mathrm{a}}\right)$ were calculated from DIC, TA, temperature, salinity, phosphate, and silicate data using the CO2SYS program (Lewis and Wallace, 1998). For the calculation, the dissociation constants for carbonic acid of Mehrbach et al. (1973) as refit by Dickson and Millero (1987) and for $\mathrm{KHSO}_{4}^{-}$of Dickson (1990) were used. The calculated $\mathrm{pH}$ was reported on total scale at a constant temperature of $25^{\circ} \mathrm{C}\left(\mathrm{pH}_{25}\right)$. The concentration of calcium $\left(\left[\mathrm{Ca}^{2+}\right]\right)$ was calculated from salinity according to Riley and Tongudai (1967). $K_{\text {sp }}$ values of aragonite and calcite were calculated after Mucci (1983). Uncertainty in the measurements of DIC and TA may have resulted in errors of about $0.01 \mathrm{pH}$ unit in the calculation of $\mathrm{pH}$, and $3 \%$ in the computation of $\Omega_{\mathrm{c}}$ and $\Omega_{\mathrm{a}}$.

\section{Results}

\subsection{Surface distributions of temperature, salinity, and carbonate parameters in spring and summer}

The distributions of sea surface temperature (SST) and salinity (SSS) in spring and summer 2009 on the ECS shelf are shown in Fig. 2. SST varied from 15.8 to $25.3^{\circ} \mathrm{C}$ and 23.3 to $29.6^{\circ} \mathrm{C}$ in spring and summer, respectively (Fig. $2 \mathrm{a}$ and b). Waters with relatively higher SST were generally confined to the southeastern part of the study area, whereas waters with relatively lower SST were mainly found in the northern and 

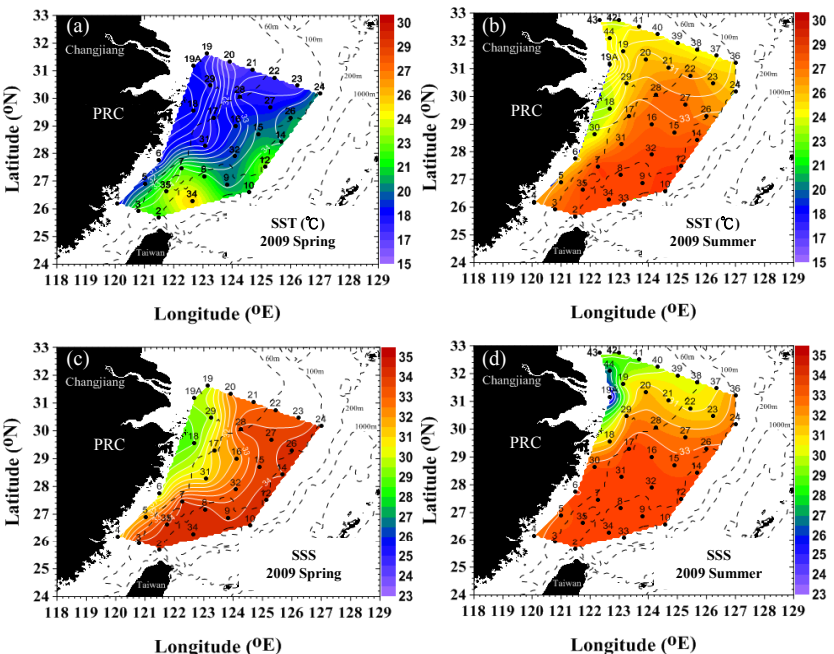

Fig. 2. Surface distributions of temperature (SST) are indicated in (a) and (b); and (c) and (d) indicate salinity (SSS) in spring (a and c) and summer (b and d) 2009 in the East China Sea.

western parts. SSS ranged from 27.9 to 34.5 in spring, and from 23.8 to 34.1 in summer (Fig. 2c and d). The higher SSS values were observed in the southeastern part of the study area for both seasons. The lower SSS values occurred mainly in the inner shelf along the coast of China in spring, and in the northwestern part of the study area in summer.

The spatial distributions of surface-water TA, DIC, $\mathrm{pH}_{25}$, $\Omega_{\mathrm{a}}$ and $\Omega_{\mathrm{c}}$ for spring and summer cruises are shown in Fig. 3a-j. TA varied from 2218 to $2284 \mu \mathrm{mol} \mathrm{kg}^{-1}$ in spring, and from 2103 to $2252 \mu \mathrm{mol} \mathrm{kg}{ }^{-1}$ in summer. The TA distribution commonly paralleled salinity: the higher TA values were mainly observed in the salty outer shelf waters, while the lower TA values were commonly found in the less saline waters, which occurred in the western and northern parts of the study area in spring and summer, respectively. In general, the distributions of SSS, SST, and TA corresponded well with the seasonal circulation pattern on the ECS shelf. Waters with high TA, SSS, and SST in the southeastern part of the study area identified the Kuroshio Current, which is the western boundary current of the North Pacific Ocean flowing northeastward along the $200 \mathrm{~m}$ isobath all year round (Fig. 1; Liu and Gan, 2012). Waters with low TA, SSS, and SST were indicative of the Changjiang diluted water (defined as water with salinity $<31$ by Gong et al, 1996), which flows southward along the coast of China during the dry season under the influence of northeast monsoon, and spreads eastward over the broad ECS during the flood season (Fig. 1; Beardsley et al., 1985).

DIC varied from 1805 to $1984 \mu \mathrm{mol} \mathrm{kg}^{-1}$ in spring, and from 1680 to $2034 \mu \mathrm{mol} \mathrm{kg}{ }^{-1}$ in summer. Similar to the distribution pattern of TA, relatively lower DIC values occurred in the nearshore area in spring but shifted to the northern part of the study area in summer, corresponding well to the
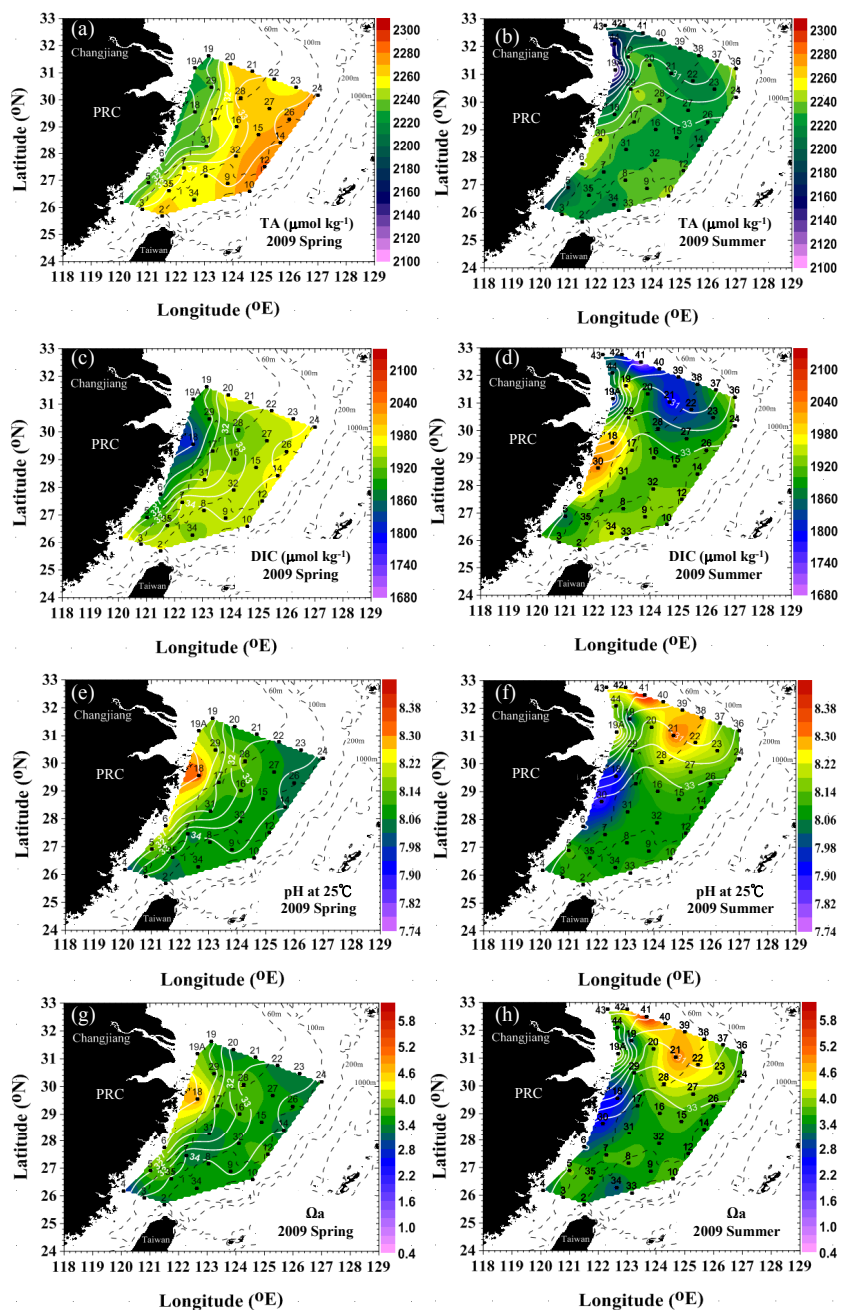

Longitude $\left({ }^{\circ} \mathbf{E}\right)$
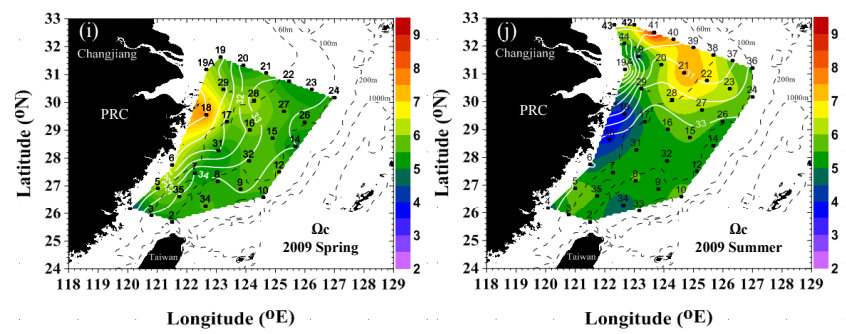

Fig. 3. Surface distributions of (a) TA in spring, (b) TA in summer, (c) DIC in spring, (d) DIC in summer, (e) $\mathrm{pH}_{25}$ in spring, (f) $\mathrm{pH} 25$ in summer, (g) Wa in spring, (h) Wa in summer, (i) Wc in spring, and (j) Wc in summer 2009 in the East China Sea. Superimposed white lines are isohalines.

seasonal dispersion of the Changjiang diluted water (CDW). The highest DIC values were present along the coast of mainland China beyond the influence of the CDW during the summertime, which was associated with the seasonal coastal upwelling induced by the summer monsoon parallel to shore (Chou et al., 2009a). $\mathrm{pH}_{25}$ varied from 7.98 to 8.34 in spring, and from 7.86 to 8.45 in summer. $\Omega_{\mathrm{a}}$ and $\Omega_{\mathrm{c}}$ varied from 2.67 to 4.84 and from 4.17 to 7.58 in spring, and from 2.50 
to 5.85 and from 3.82 to 9.02 in summer, respectively. These parameters had very similar distribution patterns, which generally mirrored that of DIC. The higher $\mathrm{pH}_{25}, \Omega_{\mathrm{a}}$ and $\Omega_{\mathrm{c}}$ values were commonly found along the coast of China in spring and in the northern part of the study area in summer, where DIC had the lowest values. In contrast, the lowest $\mathrm{pH}_{25}, \Omega_{\mathrm{a}}$ and $\Omega_{\mathrm{c}}$ values were observed in the middle nearshore area in summer, where DIC had the highest values.

Seasonally, these carbonate parameters showed the largest variation in the regions bearing distinct seasonal circulation/advection settings. The mid-coastal area, which was occupied by the CDW in spring and shifted coastal upwelling zone in summer, revealed the highest increase of DIC and the largest decrease of $\mathrm{pH}_{25}, \Omega_{\mathrm{a}}$ and $\Omega_{\mathrm{c}}$ between spring and summer. In contrast, the northern part of the study area, which was occupied by the CDW in summer but out of its influence in spring, showed the highest drawdown of DIC and the largest augmentation of $\mathrm{pH}_{25}, \Omega_{\mathrm{a}}$ and $\Omega_{\mathrm{c}}$ between spring and summer.

\subsection{Depth distributions of carbonate parameters in spring and summer}

The vertical distributions of TA, DIC, $\mathrm{pH}_{25}, \Omega_{\mathrm{a}}$ and $\Omega_{\mathrm{c}}$ along all cross-shelf transects in spring and summer are shown in Figs. 4 and 5, respectively. Similar to the pattern of surface waters, the vertical distributions of TA are generally parallel with the isohalines along all transects (panel A in Figs. 4 and 5), suggesting that salinity is the dominant factor regulating the depth distributions of TA on the ECS shelf. DIC generally increases with increasing depth at all stations, but with large spatial variation in their vertical gradients (panel B in Figs. 4 and 5). The stations impacted by the CDW generally revealed a stronger vertical gradient of DIC, in particular during the summertime. For example, at the nearshore stations on the northernmost transect $\mathrm{H}$ in summer (Stations 39-43, top panel B in Fig. 5), DIC values are as low as about 1700$1800 \mu \mathrm{mol} \mathrm{kg}^{-1}$ in surface waters, but they increased sharply to as high as about $2000-2100 \mu \mathrm{mol} \mathrm{kg}{ }^{-1}$ in bottom waters only within a depth range of approximately $40 \mathrm{~m}$. These steep gradients of DIC suggest an intensification of the biological pump in the CDW area, which is consistent with our previous investigation in summer 2007 (Chou et al., 2009b). In spring, a stronger DIC gradient can also be found at the nearshore stations influenced by the CDW (Stations 19, 29, 18 and 6 on transects G, F, E and C, respectively; panel B in Fig. 4), but it is less steep than that in summer. The weakest vertical gradients of DIC were observed at the nearshore stations on transects C, D and E in summer (Stations 6, 30 and 18, respectively). For instance, at Station 6 on transect C, DIC was $1992 \mu \mathrm{mol} \mathrm{kg}{ }^{-1}$ in surface water, but it only slightly increased to $2003 \mu \mathrm{mol} \mathrm{kg}{ }^{-1}$ in bottom water. These gentle gradients of DIC may result mainly from the coastal upwelling induced by the summer monsoon parallel to shore (south- westerly), as evidenced by a sharp shoreward uplift of DIC, $\mathrm{pH}_{25}, \Omega_{\mathrm{a}}$ and $\Omega_{\mathrm{c}}$ isoclines along the transects $\mathrm{C}, \mathrm{D}$ and $\mathrm{E}$.

In contrast to the vertically increasing trend of DIC, $\mathrm{pH}_{25}$, $\Omega_{\mathrm{a}}$ and $\Omega_{\mathrm{c}}$ commonly decrease with increasing depth, but show a similar spatial variation in their gradients: the steeper gradients of $\mathrm{pH}_{25}, \Omega_{\mathrm{a}}$ and $\Omega_{\mathrm{c}}$ were also found at the stations on the transects $\mathrm{G}$ and $\mathrm{H}$ in summer (panels $\mathrm{C}, \mathrm{D}$ and $\mathrm{E}$ in Fig. 5), and the nearshore stations on transects $\mathrm{C}$ and $\mathrm{E}$ in spring (panels C, D and E in Fig. 4), both of which were under the influence of the CDW. Meanwhile, the weakest vertical gradients of $\mathrm{pH}_{25}, \Omega_{\mathrm{a}}$ and $\Omega_{\mathrm{c}}$ occurred at the nearshore stations on transects $\mathrm{C}, \mathrm{D}$ and $\mathrm{E}$ in summer, which were affected by the coastal upwelling.

In summary, the most striking feature in the vertical distributions of carbonate parameters is that they showed an extremely steep vertical gradient in the CDW area during the summertime: the lowest DIC and the highest $\mathrm{pH}_{25}, \Omega_{\mathrm{a}}$ and $\Omega_{\mathrm{c}}$ were found in the surface water, but the highest DIC and the lowest $\mathrm{pH}_{25}, \Omega_{\mathrm{a}}$ and $\Omega_{\mathrm{c}}$ were in the bottom water. In Sections 4.3 and 4.4, we will examine the mechanism that forms such steep gradients in the CDW area and discuss its potential impact on acidification of bottom waters in the future.

\section{Discussion}

Since $\Omega_{\mathrm{c}}$ is constantly about $50 \%$ higher than $\Omega_{\mathrm{a}}$ and shows the same spatial and seasonal variations as $\Omega_{\mathrm{a}}$, the following discussion focuses only on $\Omega_{\mathrm{a}}$, and data for $\Omega_{\mathrm{c}}$ are not plotted.

\subsection{The role of freshwater runoff on $\Omega$ variation in the coastal zone}

It is known that nearly all of the world's large rivers have lower carbonate and calcium concentrations (and thus lower $\Omega$ ) than receiving ocean water (Meybeck, 1987; Cai et al., 2008). The mixing of freshwater with seawater, therefore, can effectively suppress $\Omega_{\mathrm{a}}$ in the nearshore area. For instance, Salisbury (2008) reported that freshwater runoff can significantly lower $\Omega_{\mathrm{a}}$ in the plume areas of the Amazon and Orinoco rivers (the first and the third largest rivers in the world). The author also suggested that acidic river influx with low $\Omega_{\mathrm{a}}$ may have the potential to interfere with early stages of shellfish development in the coastal zone. Similarly, Jiang et al. (2010) recently found that due to inputs of low-saturation-state freshwater from land, $\Omega_{\mathrm{a}}$ showed an offshore increasing trend on the Southeastern US Continental Shelf, on which a strongly positive correlation between $\Omega_{\mathrm{a}}$ and salinity was observed.

In stark contrast to the expected comparatively lower $\Omega_{\mathrm{a}}$ in the freshwater-impacted area, our results show that the highest $\Omega_{\mathrm{a}}$ values were generally confined to the CDW with the lowest salinity on the ECS shelf (Fig. 3g and h). We suggest that this discrepancy may mainly result from the concurrently 
(A) TA $\left(\mu \mathrm{mol} \mathrm{kg}^{-1}\right)$
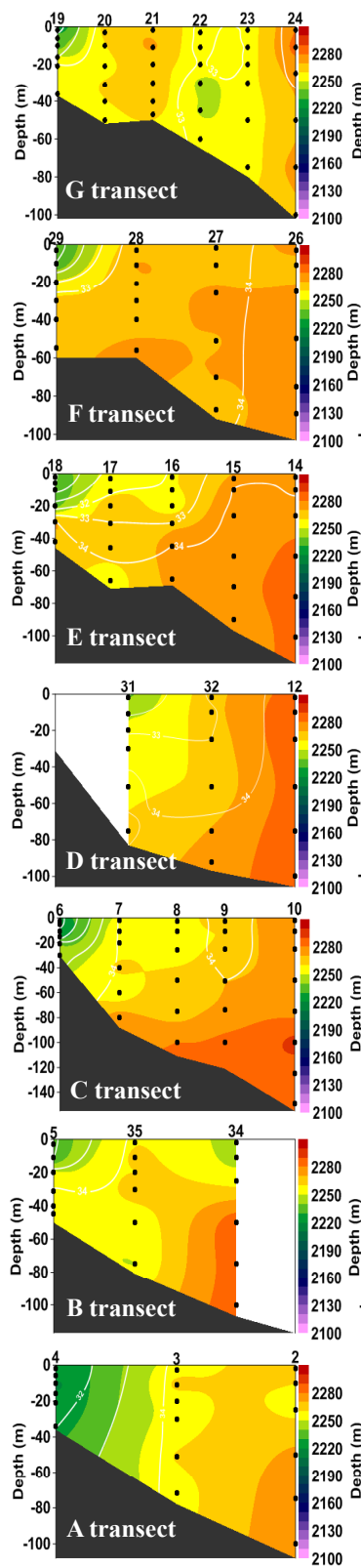

(B) DIC $\left(\mu \mathrm{mol} \mathrm{kg}{ }^{-1}\right)$
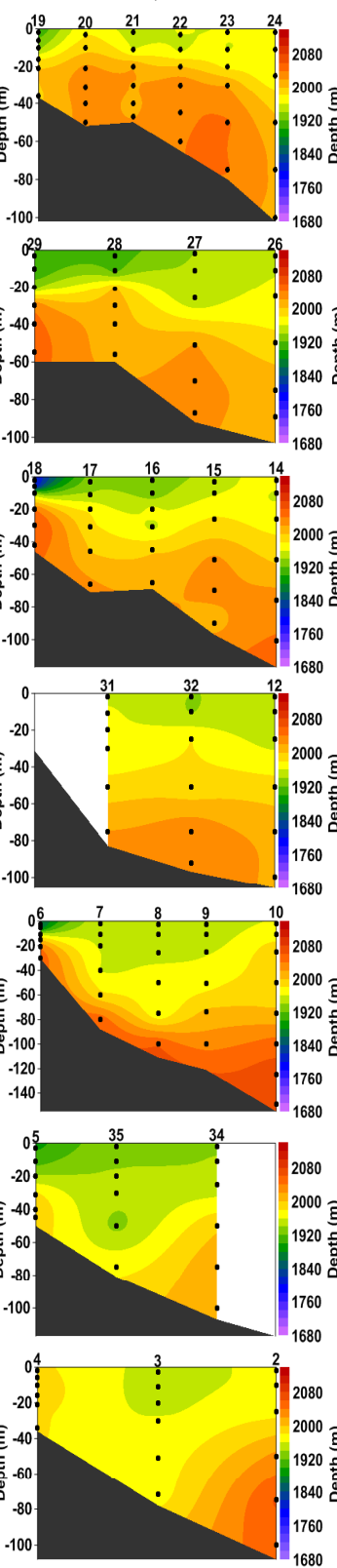

(C) $\mathrm{pH}$ at $25^{\circ} \mathrm{C}$
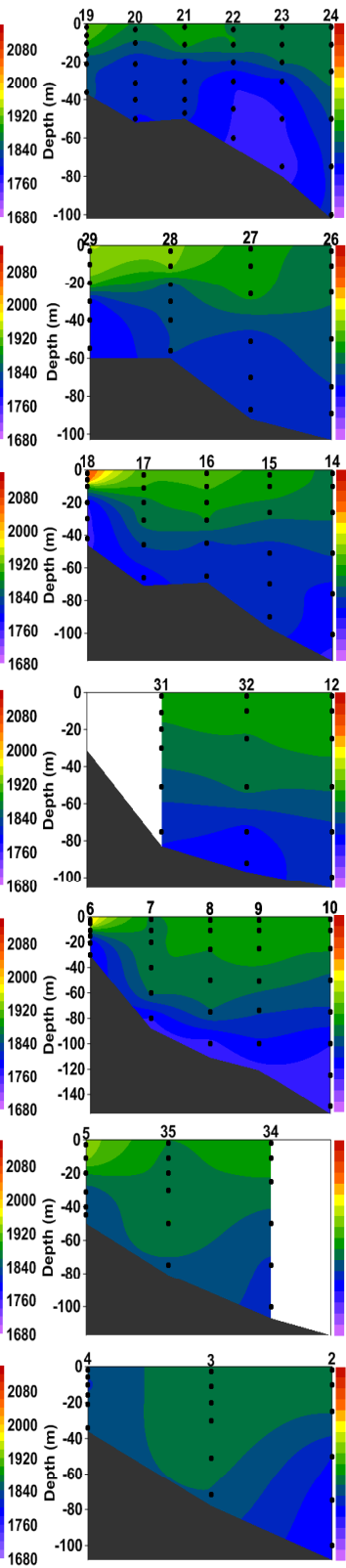

(D) $\Omega \mathrm{a}$
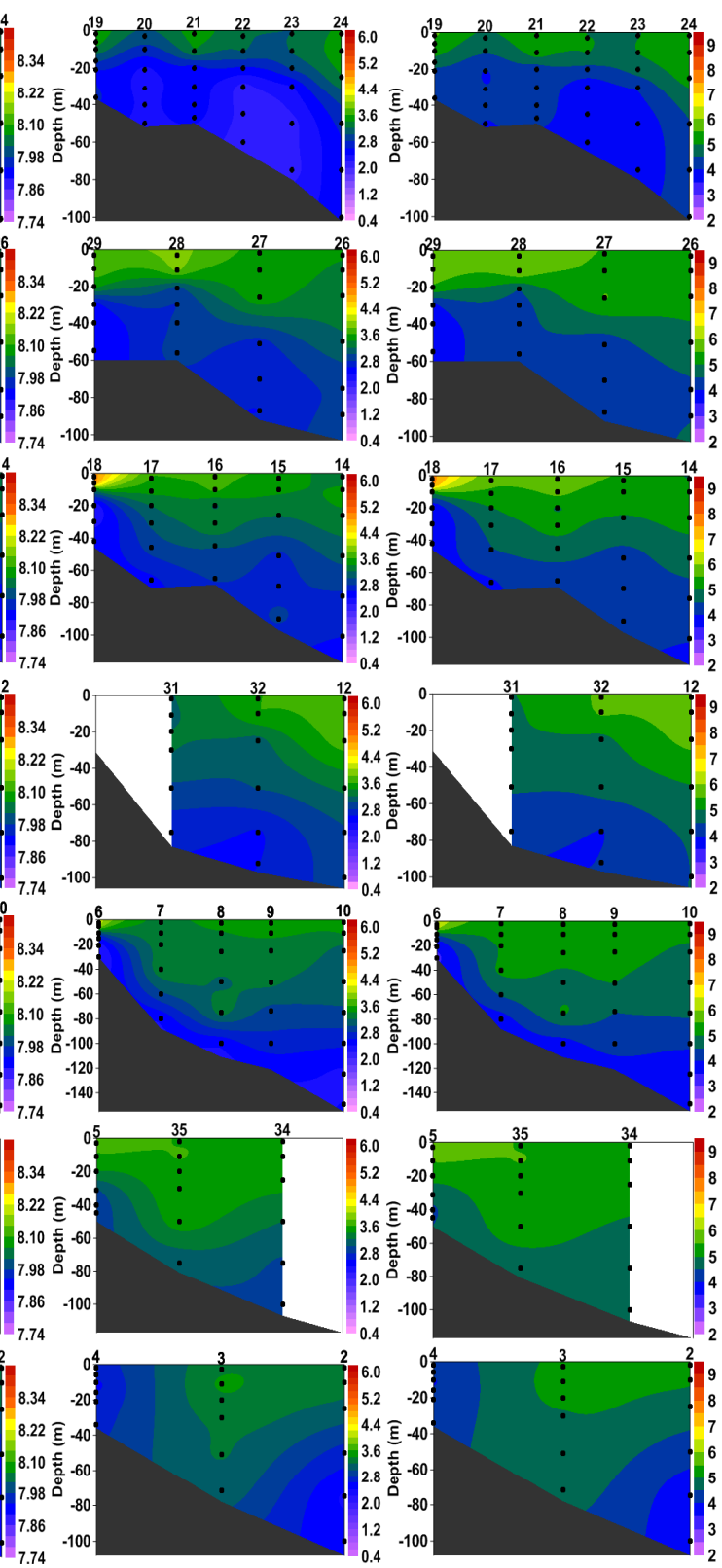

(E) $\Omega \mathbf{c}$
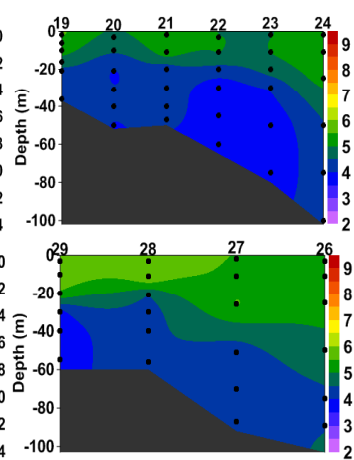

Fig. 4. Vertical distributions of TA, DIC, $\mathrm{pH}$ at $25^{\circ} \mathrm{C}, \Omega_{c}$ and $\Omega_{\mathrm{a}}$ along the A to G transects in the East China Sea in spring 2009. Superimposed white lines on TA distributions are isohalines.

elevated biological production stimulated by the enormous nutrient discharge from the Changjiang runoff, evidenced by the distributions of DO and Chl $a$ (Fig. 6). The photosynthetic uptake of $\mathrm{CO}_{2}$ through biological production may decrease DIC and the ratio of DIC to TA, thereby increasing $\Omega_{\mathrm{a}}$ (Bates et al., 2009).

Figure $7 \mathrm{a}$ and $\mathrm{b}$ show the relationships of DIC and $\Omega_{\mathrm{a}}$ vs. salinity, respectively. The superimposed lines in both plots represent the seasonal hypothetical mixing relationships between freshwater and seawater end-members in spring (dashed lines) and summer (dashed-dotted lines). The TA and DIC data reported by Zhai et al. (2007) were used as freshwater end-members for the Changiiang runoff, whereas the average surface data at stations 10,12 and 14 from this study were chosen to represent the seasonal seawater endmembers (Table 1). It is noteworthy that unlike the linear relationship between DIC and salinity, the $\Omega_{\mathrm{a}}$ change is nonlinear during mixing. The hypothetical mixing curve for $\Omega_{\mathrm{a}}$ is calculated indirectly based on the fact that both DIC and TA mix conservatively with salinity, and thus $\Omega_{\mathrm{a}}$ can be 
(A) TA $\left.(\mu \mathrm{mol} \mathrm{kg})^{-1}\right)$
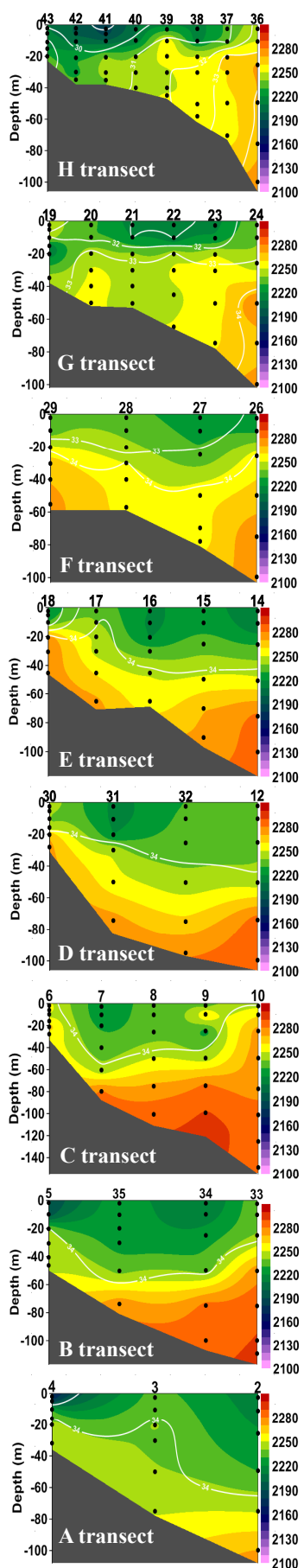

(B) DIC $\left(\mu \mathrm{mol} \mathrm{kg}{ }^{-1}\right)$
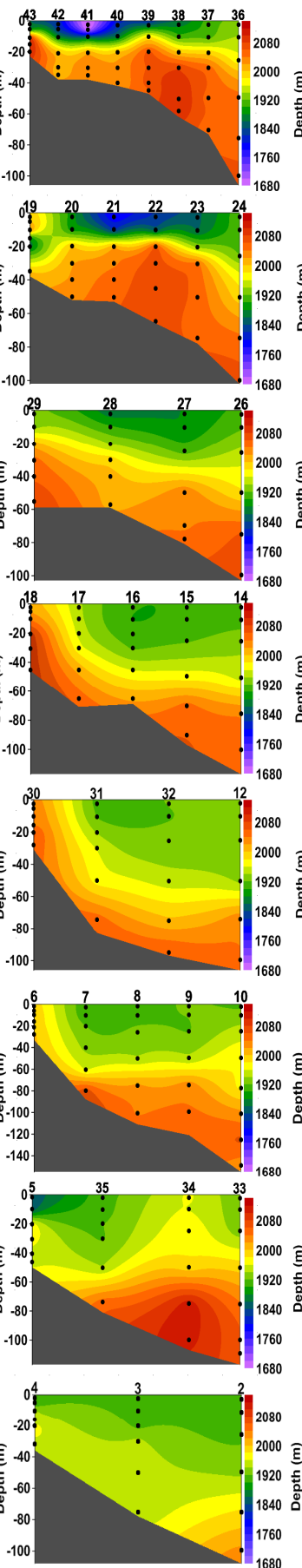

(C) $\mathrm{pH}$ at $25{ }^{\circ} \mathrm{C}$
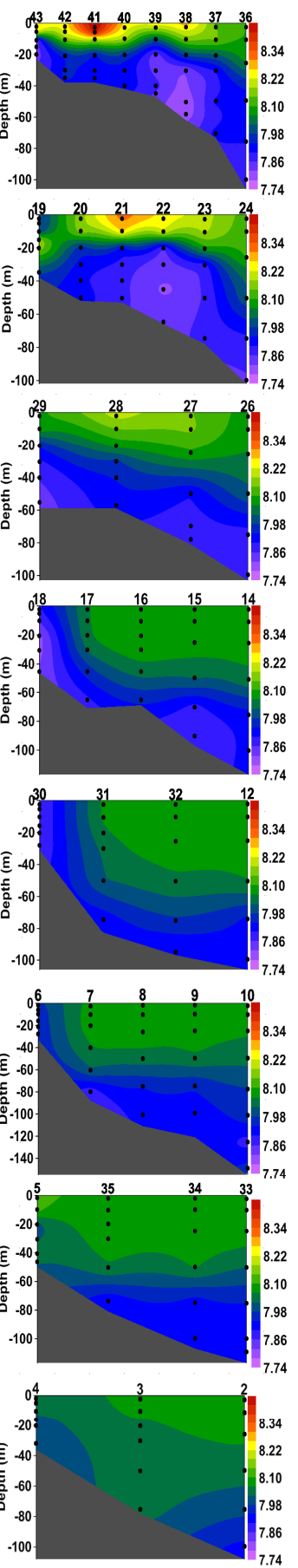

(D) $\Omega \mathbf{a}$
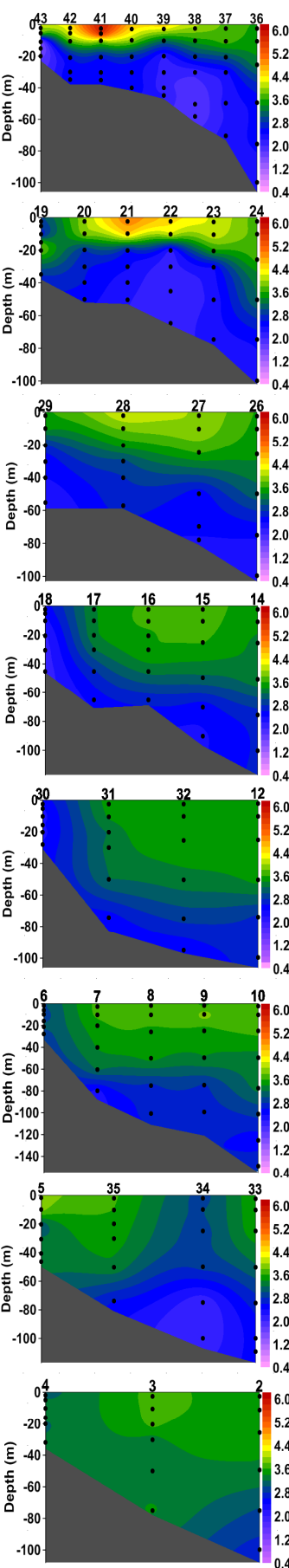

(E) $\Omega$ c
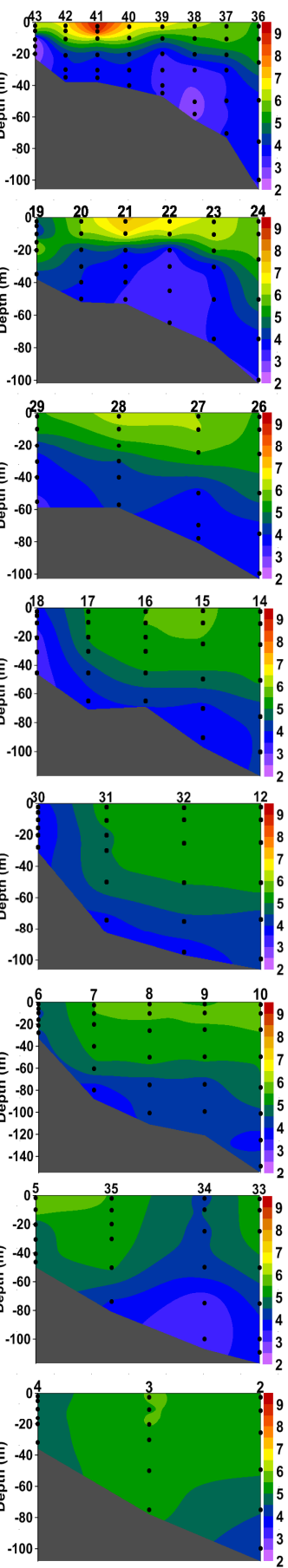

Fig. 5. Vertical distributions of TA, DIC, $\mathrm{pH}_{25}, \Omega_{\mathrm{c}}$ and $\Omega_{\mathrm{a}}$ along the A to $\mathrm{H}$ transects in the East China Sea in summer 2009. Superimposed white lines on TA distributions are isohalines.

computed from its corresponding DIC and TA values using the CO2SYS program. The DIC and $\Omega_{\mathrm{a}}$ vs. salinity plots show that, in the low salinity CDW $(S<31)$, DIC is generally below the theoretical mixing line (Fig. 7a), while $\Omega_{\mathrm{a}}$ is above it (Fig. 7b). This divergence implies that enhanced biological production fueled by nutrient discharge from the Changjiang may consume substantial DIC, thereby increasing $\Omega_{\mathrm{a}}$ in the CDW. To justify this postulation, we further calculated the deviations of the measured DIC and $\Omega_{\mathrm{a}}$ from their corresponding seasonal theoretical mixing values (referred to 
Table 1. The seasonal freshwater and seawater end-members of TA and DIC in spring and summer.

\begin{tabular}{|c|c|c|c|c|c|c|}
\hline & \multicolumn{3}{|c|}{ Freshwater end-member } & \multicolumn{3}{|c|}{ Seawater end-member } \\
\hline & TA & DIC & Source & TA & DIC & Source \\
\hline Spring & 1600 & 1600 & Zhai et al. (2007) & 2277 & 1965 & $\begin{array}{l}\text { The average values at stations } \\
10,12 \text {, and } 14 \text { in spring } 2009 .\end{array}$ \\
\hline Summer & 1790 & 1790 & Zhai et al. (2007) & 2231 & 1918 & $\begin{array}{l}\text { The average values at stations } \\
10,12 \text {, and } 14 \text { in summer } 2009 \text {. }\end{array}$ \\
\hline
\end{tabular}

Unit: $\mu \mathrm{mol} \mathrm{kg}-1$

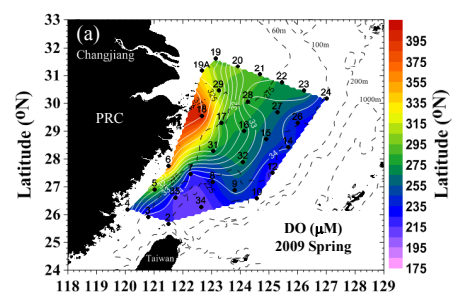
Longitude ( $\left.{ }^{\mathbf{O}} \mathbf{E}\right)$
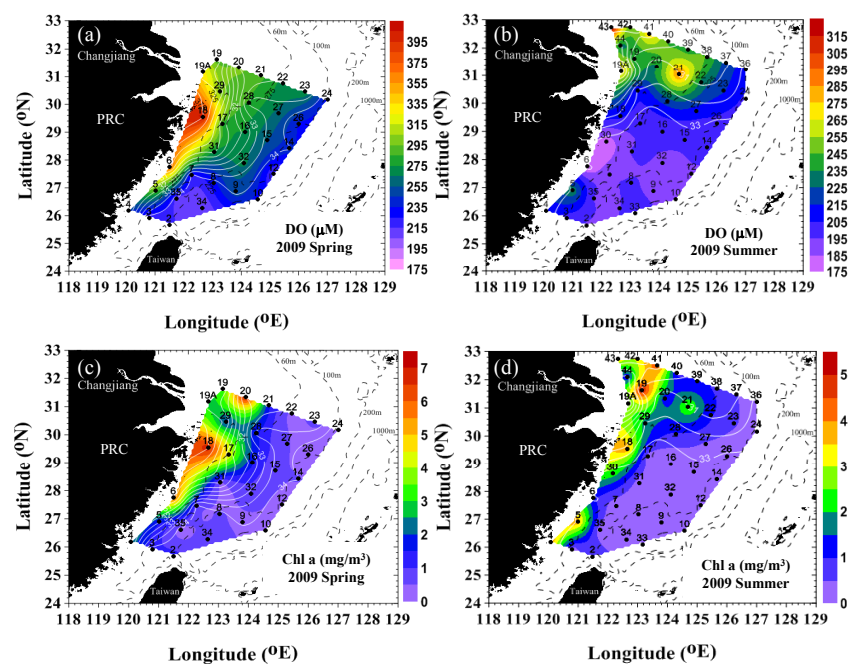
Longitude ( $\left.{ }^{\circ} \mathrm{E}\right)$

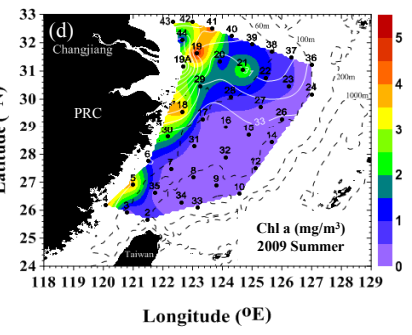

Fig. 6. Surface distributions of (a) dissolved oxygen (DO) in spring, (b) DO in summer, (c) $\mathrm{Chl}$ a in spring, and (d) Chl $a$ in summer 2009 in the East China Sea. Superimposed white lines are isohalines.

as $\Delta$ DIC and $\Delta \Omega_{\mathrm{a}}$ in Fig. $7 \mathrm{c}$ ). The calculated result shows a strongly negative correlation between $\Delta \mathrm{DIC}$ and $\Delta \Omega_{\mathrm{a}}$ in both spring and summer $(r=-0.85$ and -0.95 in spring and summer, respectively, $p<0.05$; Fig. 7c), lending support to the hypothesis that biologically induced DIC drawdown may be the driving force that accounts for the observed high $\Omega_{\mathrm{a}}$ in the CDW. In fact, this result agrees well with previous findings that due to the favorable conditions (i.e., high availability of light and nutrients and warm temperature), the CDW area generally features very high Chl $a$ concentrations (Gong et al., 2011; Hung et al., 2009) and acts as a strong sink of atmospheric $\mathrm{CO}_{2}$ in late spring and summer (Zhai and Dai, 2009; Chou et al., 2009a).

In summary, our results demonstrate that the enhancement of biological production can overwhelm the dilution effect that regulates $\Omega_{\mathrm{a}}$ variation in the Changjiang plume area during the study period. Consequently, mixing with river discharge may not necessarily lower $\Omega_{\mathrm{a}}$ in the surface waters of the continental shelf. Rivers with high TA that are highly eutrophic (e.g., the Changjiang) tend to elevate $\Omega_{\mathrm{a}}$, while rivers with low TA that are less eutrophic (e.g., the Amazon River) tend to lower $\Omega_{\mathrm{a}}$ in the receiving seawater.

\subsection{Aragonite saturation states of surface waters in 2100}

Previous studies have shown that the ECS shelf acts as an important sink of atmospheric $\mathrm{CO}_{2}$ all year round (Tsunogai et al., 1999; Peng et al, 1999; Wang et al., 2000; Shim et al., 2007; Zhai and Dai, 2009; Chou et al., 2009a and 2011). Consequently, $\Omega$ in surface water would be continuously decreasing in response to anthropogenic $\mathrm{CO}_{2}$ absorption. Here we estimate the future change of $\Omega_{\mathrm{a}}$ in the ECS by the year 2100. This projection was conducted by the conventional equilibrium approach (Orr, 2011) with the following assumptions: (1) equilibrium between atmospheric and seawater $\mathrm{CO}_{2}$; (2) the sea surface salinity and alkalinity remain invariant; (3) sea surface temperature increases by $2{ }^{\circ} \mathrm{C}$ (McNeil and Matear, 2007); and (4) the atmospheric $\mathrm{CO}_{2}$ concentration reaches 723 ppmv (according to the IS92a scenario given in Annex II of the IPCC Third Assessment Working Group I report; http://www.ipcc-data.org/observ/ddc_co2.html).

Results show that $\Omega_{\mathrm{a}}$ will vary from 1.47 to 2.18 in spring (Fig. 8a), and from 1.69 to 2.47 in summer (Fig. 8b), suggesting that the ECS will remain supersaturated with respect to aragonite even until the end of this century. It is known that calcareous organisms usually require seawater $\Omega$ values much higher than 1 to achieve optimal growth. Therefore, even though surface waters on the ECS shelf will not become corrosive to carbonate minerals before 2100, the rapid drop in saturation states could have negative impacts on the rate of calcification of calcium carbonate shell (Ries et al., 2009) and juvenile recruitment rates (Gazeau et al., 2007).

Furthermore, the projected $\Omega_{\mathrm{a}}$ reductions between the present day and the year 2100 show distinct spatial variations that are similar to those for the present $\Omega_{\mathrm{a}}$ distributions: the largest drop of $\Omega_{\mathrm{a}}$ was found in the coastal area in spring (Fig. 8c) and in the northern part in summer (Fig. 8d), which has the highest $\Omega_{\mathrm{a}}$ at present (Fig. 3i and j), whereas the smallest changes generally occurred in the southeastern part of the study area, which is characterized by low $\Omega_{\mathrm{a}}$ now.

We suggest that the spatial variations of the projected $\Omega_{\mathrm{a}}$ decline are largely controlled by the chemical capacity of 

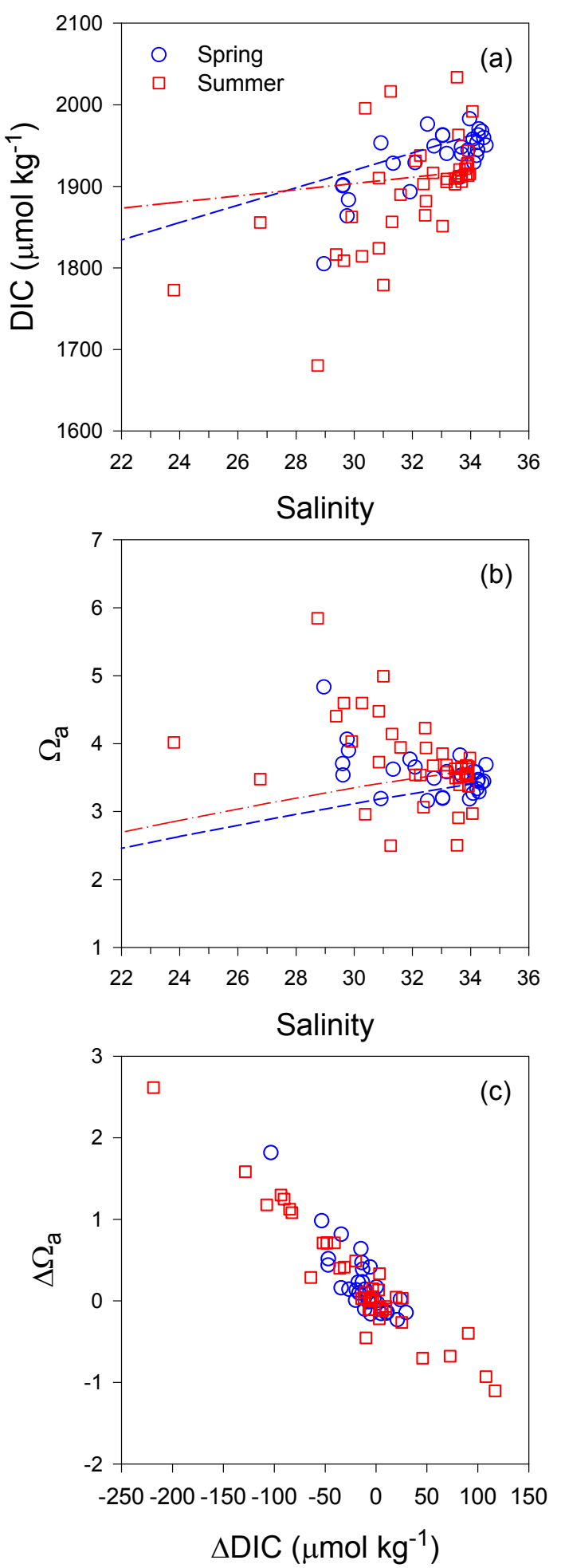

Fig. 7. Plots of (a) DIC vs. salinity, (b) $\Omega_{\mathrm{a}}$ vs. salinity, and (c) $\Delta \Omega_{\mathrm{a}}$ vs. $\triangle \mathrm{DIC}$ for the surface waters in the East China Sea in spring and summer 2009. The superimposed lines represent the hypothetical conservative mixing lines between the freshwater and seawater end-members. $\Delta \Omega_{\mathrm{a}}$ and $\Delta \mathrm{DIC}$ denote the difference between the measured values and the hypothetical conservative-mixing values.
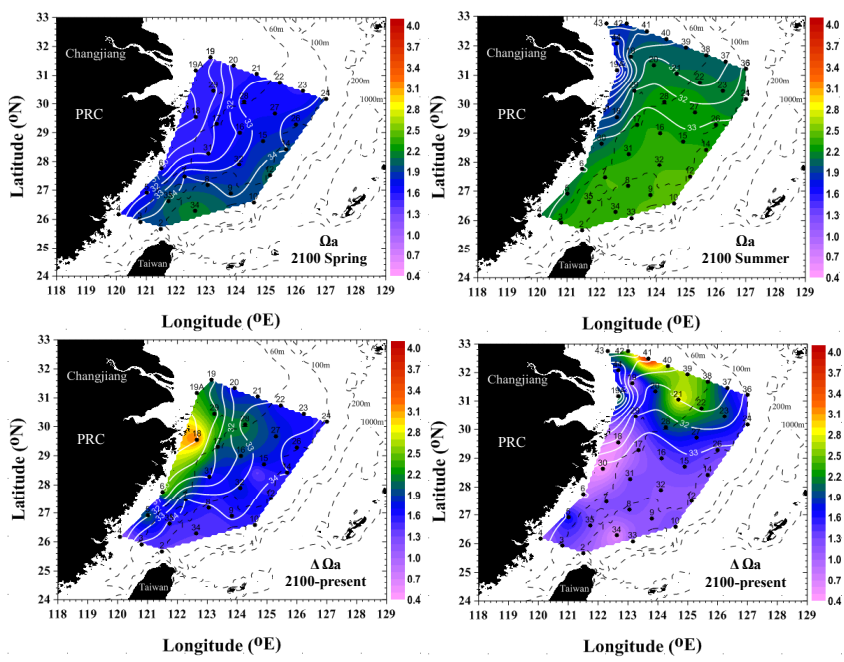

Fig. 8. (a) and (b) show predicted surface water $\Omega_{\mathrm{a}}$ on the East China Sea shelf in spring and summer by the year 2100 , respectively. (c) and (d) show the difference of $\Omega_{\mathrm{a}}$ between the predicted $\Omega_{\mathrm{a}}$ in 2100 and its present value $\left(\Delta \Omega_{\mathrm{a}}\right)$ in spring and summer, respectively. Superimposed white lines are isohalines.

surface waters to take up atmospheric $\mathrm{CO}_{2}$. Theoretically, the chemical potential of seawater to sequester atmospheric $\mathrm{CO}_{2}$ is inversely proportional to the value of the Revelle factor, which is defined as the ratio of the relative changes in $p \mathrm{CO}_{2}$ and DIC (Revelle and Suess, 1957). Due to the carbonate buffering effect, the value of the Revelle factor is proportional to the DIC/TA ratio (Fig. 9a; Sarmiento and Gruber, 2006). As discussed earlier, the observed high $\Omega_{\mathrm{a}}$ in the present study resulted mainly from the elevated biological production fueled by the nutrient discharge from the Changjiang. The enhancement of biological production may also lower the DIC/TA ratio (and thus reduce the Revelle factor), thereby rendering surface waters chemically suitable for taking up more atmospheric $\mathrm{CO}_{2}$ (thus leading to a potentially larger $\Omega_{\mathrm{a}}$ decrease). As a result, under the assumption of air-sea equilibrium, the projected $\Omega_{\mathrm{a}}$ decrease between the present day and the year 2100 would be larger for waters with a higher chemical potential for atmospheric $\mathrm{CO}_{2}$ sequestration (corresponding to the larger reciprocal of the Revelle factor in Fig. 9b), suggesting that the projected $\Omega_{\mathrm{a}}$ decline in the highly productive CDW area may represent a high-end estimate.

It is noteworthy that the above projection is based on only long-term changes in atmospheric $\mathrm{CO}_{2}$ and the assumption of air-sea equilibrium, both of which work well over most of the global open ocean (Orr, 2011). However, for the coastal waters the carbonate saturation states and air-sea equilibrium level could also be affected by other processes, such as freshwater runoff (Salisbury et al., 2008), atmospheric deposition of anthropogenic nitrogen and sulfur (Doney et al., 2007), and delivery of terrestrial nutrients and organic matter (Cai et 

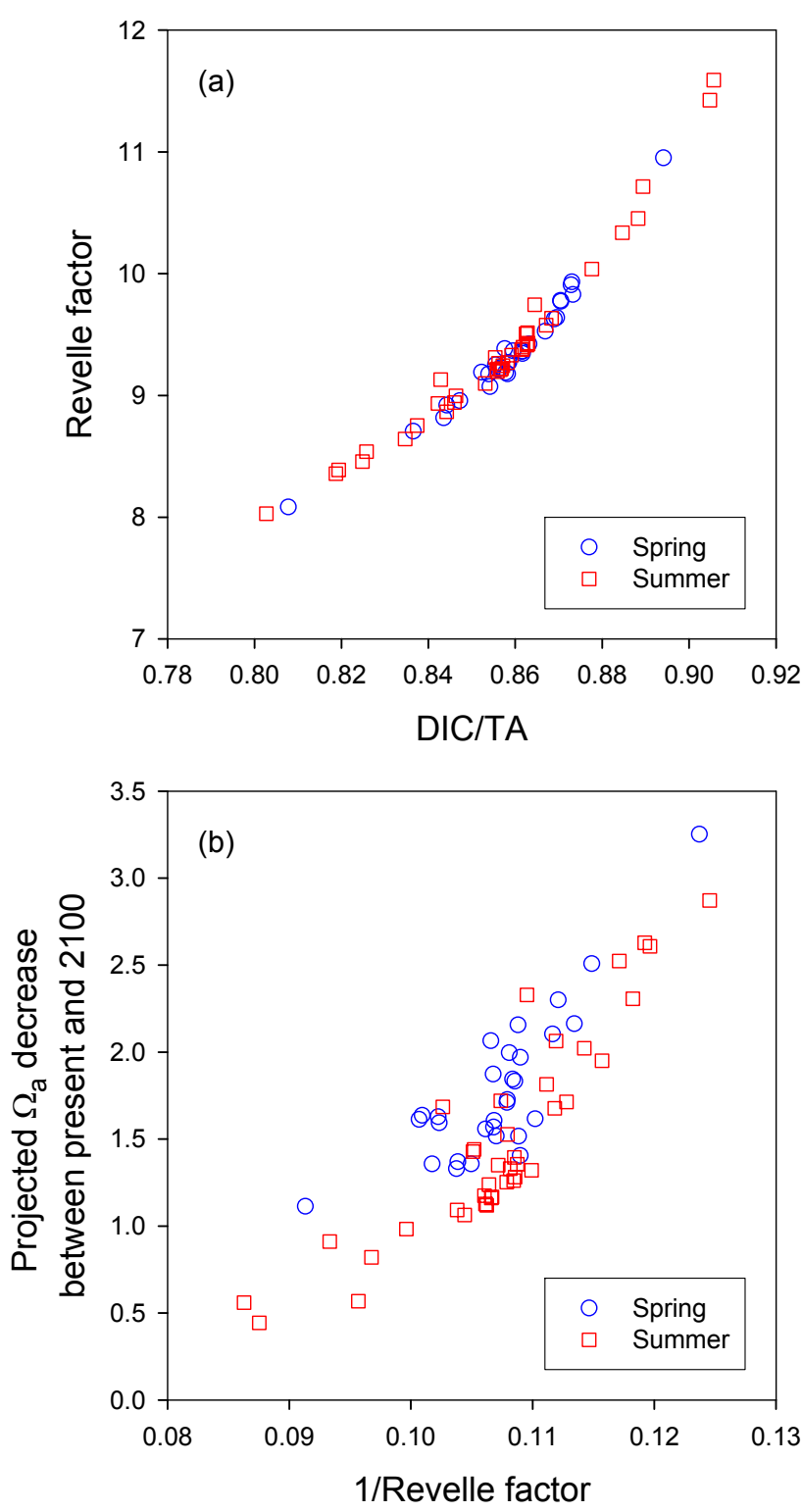

Fig. 9. Plots of (a) Revelle factor vs. DIC / TA ratio, and (b) difference of $\Omega_{\mathrm{a}}$ between the predicted $\Omega_{\mathrm{a}}$ in 2100 and its present value $\left(\Delta \Omega_{\mathrm{a}}\right)$ vs. the reciprocal of the Revelle factor (1/Revelle factor) for the surface waters in the East China Sea during spring and summer 2009.

al., 2011). In fact, Borges and Gypens (2010) proposed that in highly productive coastal environments the effect of excess nutrient delivery (eutrophication) may exert a stronger influence on regulating future carbonate saturation state changes compared with ocean acidification due to increasing atmospheric $\mathrm{CO}_{2}$. Recently, Wang (2006) has reported that increasing riverine loads of nutrients have caused a significant augmentation of summertime Chl $a$ concentration in surface waters in the Changjiang plume area over recent decades. The nutrient export into the ECS is expected to continue rapidly increasing in the next $50 \mathrm{yr}$ (Seitzinger et al., 2010), which can enhance biological production and thereby mitigate the effect of ocean acidification due to anthropogenic $\mathrm{CO}_{2}$ uptake in surface waters. In this regard, our projection in the surface water may therefore represent an overall highend estimate of the change in carbonate saturation states.

\subsection{Biologically induced acidification in the bottom water of the Changjiang plume area in summer}

As mentioned in Sect. 3.2 and shown in Fig. 10, both $\mathrm{pH}_{25}$ and $\Omega$ values demonstrate the strongest vertical gradients at the stations impacted by the CDW during the summertime. In Sect. 4.1, we have clearly shown that the highest surface $\mathrm{pH}_{25}$ and $\Omega$ values in the CDW in summer result mainly from elevated biological production stimulated by the nutrient discharge from the Changjiang runoff. On the other hand, the elevated biological production in the surface layer would export more particles to bottom waters, thereby rapidly transferring organic matter from surface to depth (Iseki et al., 2003; Hung et al., 2010, 2013). In combination with the strong stratification of the water column in summer (Chou et al., 2009b), which can isolate bottom waters from exchanging gas with surface waters, the remineralization of organic matter in the water column and sediment rapidly increased DIC concentrations, thereby depressing $\mathrm{pH}_{25}$ and $\Omega$ to their minimum values in the bottom water in the Changjiang plume area in summer. The proposed process is supported by the strongly negative correlations between $\mathrm{pH}_{25} / \Omega_{\mathrm{a}}$ and DIC for bottom waters (Fig. 11).

A similar seasonal divergence of $\mathrm{pH}$ and $\Omega$ in surface and subsurface waters has been found in the polar shelves during the productive season (e.g., in the western Arctic Ocean (Bates et al, 2009) and in the Bering Sea (Mathis et al., 2011a and 2011b)). In these studies, the authors described the above process in terms of a "phytoplankton-carbonate saturation state (PhyCaSS)" interaction, and suggested that a combination of addition of anthropogenic $\mathrm{CO}_{2}$ to the ocean and the natural seasonal PhyCaSS interaction has tipped subsurface waters below the saturation state threshold for aragonite $\left(\Omega_{\mathrm{a}}=1\right)$ in the high-latitude shelves during the productive season. Despite the analogous impacts existing in our study area (namely uptake of anthropogenic $\mathrm{CO}_{2}$ and the PhyCaSS interaction), the present results show that the bottom water on the ECS shelf is currently still supersaturated with respect to aragonite $\left(\Omega_{\mathrm{a}}>1\right)$, even in the CDW area in summer. This discrepancy can be partially attributed to the fact that the higher temperature on the subtropical ECS shelf decreases the solubility of $\mathrm{CO}_{2}$ and preconditions the bottom water to have lower DIC / TA ratio and thus higher carbonate saturation states compared to those in the cold bottom water on polar shelves.

However, it is noteworthy that the ECS is one of the shelves most impacted by anthropogenic enhancement of nutrient discharge from large rivers. A recent study has shown 


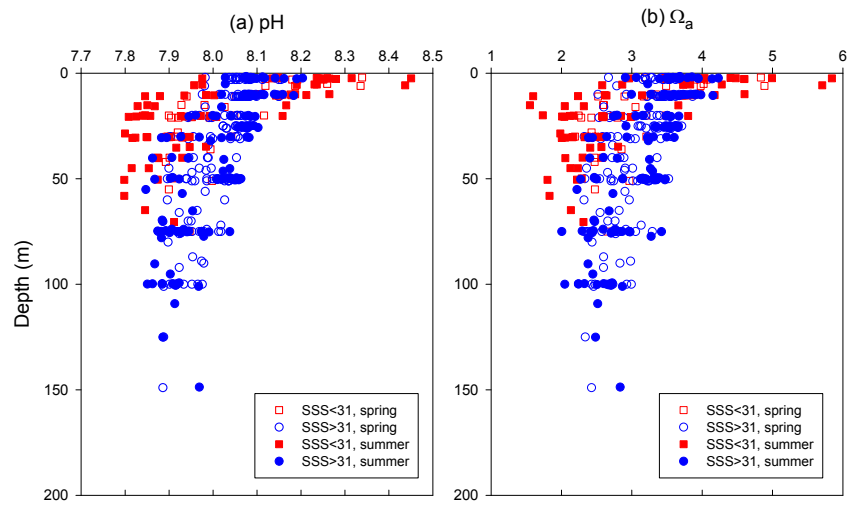

Fig. 10. Depth profiles of (a) $\mathrm{pH}_{25}$ and (b) $\Omega_{\mathrm{a}}$ over the East China Sea shelf in spring and summer 2009. Squares and circles denote the data in (SSS < 31) and out (SSS > 31) of the Changjiang plume area, respectively. SSS: sea surface salinity.

that dissolved oxygen concentrations in the bottom water of the Changjiang plume area in summer have gradually decreased (Ning et al., 2011), suggesting a trend of increasing eutrophication over recent decades. As mentioned earlier, the nutrient export into the ECS is anticipated to be continuously increasing, which may further amplify the PhyCaSS interaction and thereby enhance the suppression of $\mathrm{pH}$ and $\Omega$ at depth. Consequently, the bottom waters in the highly eutrophic Changiiang plume would acidify more readily and approach carbonate mineral undersaturation $(\Omega<1)$ faster than other coastal zones without the influence of eutrophication. In fact, Cai et al. (2011) recently showed that the synergistic effect between eutrophication and increasing atmospheric $\mathrm{CO}_{2}$ would render the bottom water in the subtropical northern Gulf of Mexico corrosive within this century. Analogously, we suggest that a similar impact is also likely to occur in the Changjiang plume area in the near future if eutrophication cannot be adequately reduced.

\subsection{Projection of aragonite saturation states in bottom waters of the Changjiang plume}

In order to simulate the future change of saturation state in bottom waters of the Changjiang plume, we first take the average of the summertime bottom-water values from the stations covered by the CDW (SSS $<31$; Stations 19, $19 \mathrm{~A}, 21-22,37-44)$ to serve as the typical conditions for bottom water at the present time (DIC $=2053 \mu \mathrm{mol} \mathrm{kg}{ }^{-1}$, $\mathrm{TA}=2245 \mu \mathrm{mol} \mathrm{kg}-1, \mathrm{pH}_{25}=7.877, \Omega_{\mathrm{a}}=2.23, \Omega_{\mathrm{c}}=3.47$ ). We then estimate how much DIC will be added to the bottom water in response to the increasing atmospheric $\mathrm{CO}_{2}\left(\Delta \mathrm{DIC}_{\mathrm{ac}}\right)$ from the present to the end of this century. To determine $\triangle \mathrm{DIC}_{\mathrm{ac}}$, we used representative surface water conditions observed during our summer cruise in 2009 (i.e., the average values for water samples $50 \mathrm{~m}$ from all stations except those influenced by the CDW
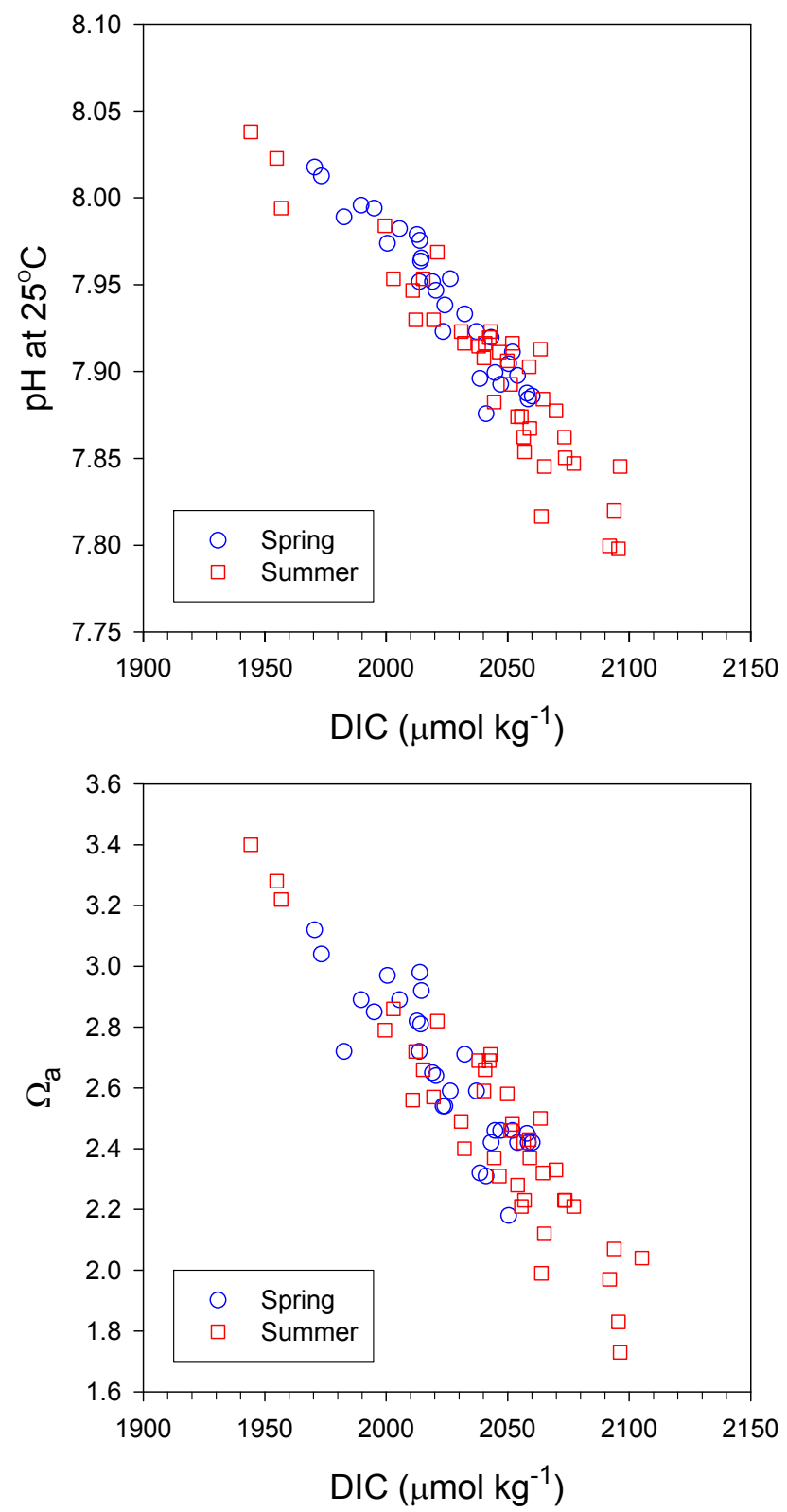

Fig. 11. Plots of (a) $\mathrm{pH}_{25}$ vs. DIC and (b) $\Omega_{\mathrm{a}}$ vs. DIC for the bottom waters in the East China Sea during spring and summer 2009.

(Stations 19, 19A, 21-22, 37-44) and coastal upwelling (Stations 6, 7, 17, 18, 30 and 31); $S=33.5, T=25.4{ }^{\circ} \mathrm{C}$, silicate $=4.97 \mu \mathrm{mol} \mathrm{kg}{ }^{-1}, \quad$ phosphate $=0.14 \mu \mathrm{mol} \mathrm{kg}{ }^{-1}$, $\mathrm{TA}=2238 \mu \mathrm{mol} \mathrm{kg}{ }^{-1}$, DIC $=1939 \mu \mathrm{mol} \mathrm{kg}{ }^{-1}$ ). Calculated $p \mathrm{CO}_{2}$ for this water mass is $370 \mu \mathrm{atm}$, which is equivalent to dry air $x \mathrm{CO}_{2}$ of $380 \mathrm{ppm}$. Assuming equilibrium between the atmosphere and this representative water mass, the equilibrated DIC at higher $\mathrm{CO}_{2}$ levels in the future was calculated by applying the atmospheric $\mathrm{CO}_{2}$ scenario of IPCC IS92a, provided that other parameters are kept constant (salinity, temperature, silicate, phosphate and TA). The difference 
between the calculated equilibrated DIC and the present DIC $\left(1939 \mu \mathrm{mol} \mathrm{kg}{ }^{-1}\right)$ denotes the DIC increase caused by the increasing atmospheric $\mathrm{CO}_{2}$ (i.e., $\Delta \mathrm{DIC}_{\mathrm{ac}}$ ). We presume that the bottom water in the Changjiang plume was derived from the average shelf water, so that the calculated $\Delta \mathrm{DIC}_{\mathrm{ac}}$ for the representative water mass can apply to the bottom water. We add $\triangle \mathrm{DIC}_{\mathrm{ac}}$ to the typical DIC of bottom water at present $\left(2053 \mu \mathrm{mol} \mathrm{kg}^{-1}\right)$ while keeping the remaining parameters unchanged, and recalculate $\Omega_{\mathrm{a}}$. The recalculated result shows that $\Omega_{a}$ will gradually decline from about 2.2 at present to about 1.2 at the end of this century (solid line in Fig. 12), suggesting that the bottom water of the Changjiang plume will remain supersaturated with respect to aragonite before 2100, if only the effect of atmospheric $\mathrm{CO}_{2}$ increase is taken into account.

In order to quantify the potential impact of increasing eutrophication on $\Omega_{\mathrm{a}}$ in bottom waters of the Changjiang plume further, using the same method, we first estimate how much DIC and TA will be added and consumed, respectively, to the bottom water due to the increasing eutrophication $\left(\Delta \mathrm{DIC}_{\mathrm{eu}}\right.$ and $\left.\Delta \mathrm{TA}_{\mathrm{eu}}\right)$. Recently, Ning et al. (2011) reported that worsening eutrophication has led to a dissolved oxygen (DO) concentration decrease at a rate of $0.72 \mu \mathrm{mol} \mathrm{yr}^{-1}$ from 1975 to 1995 . Assuming that DO concentrations will continue declining at this rate from the present to 2100, the corresponding DIC increase rate can be computed using the Redfield ratio $(\mathrm{C}: \mathrm{O}=106: 138$; DIC increasing rate $=0.72 \times 106 / 138=0.55 \mu \mathrm{mol} \mathrm{yr}^{-1}$ ), while the TA decreasing rate can be estimated by the DO declining rate with a coefficient of -0.119 after Feely et al. (2002) (TA decreasing rate $=-0.119 \times 0.72=-0.086 \mu \mathrm{mol} \mathrm{yr}^{-1}$ ). We add $\Delta \mathrm{DIC}_{\mathrm{eu}}$ and $\Delta \mathrm{TA}_{\mathrm{eu}}$ to the sum of $\Delta \mathrm{DIC}_{\mathrm{ac}}$ and the typical DIC and to the typical TA, respectively, in bottom water at present, and then re-recalculate $\Omega_{\mathrm{a}}$. The re-recalculated result demonstrates that $\Omega_{\mathrm{a}}$ in the bottom water of the Changjiang plume will become less than 1 (undersaturated) between the years 2075 and 2080 (dashed line in Fig. 12). It is noteworthy that the uncertainty in the presumed DO declining rate may cause a minor error in the projected decreasing rate of $\Omega_{\mathrm{a}}$ (e.g., an increase of $300 \%$ in the presumed DO decreasing rate $\left(-0.36\right.$ to $\left.-1.08 \mu \mathrm{mol} \mathrm{yr}^{-1}\right)$ may cause a corresponding increase in the projected $\Omega_{\mathrm{a}}$ declining rate by $21 \%\left(-0.14\right.$ to $\left.\left.-0.17 \mathrm{yr}^{-1}\right)\right)$. In summary, the simulation shows that the synergistic effect of the increasing atmospheric $\mathrm{CO}_{2}$ and the worsening eutrophication will likely push the bottom water of the Changjiang plume to be corrosive to aragonite by the end of this century, which is generally believed to be harmful to marine calcifiers. If some calcifying components of the benthos are negatively impacted, then the community structure and support for higher trophic levels may change. As a result, the highly productive benthic ecosystem in the Changjiang plume, which supports extensive shellfish fisheries, will be at increased risk of suffering the negative effects of ocean acidification.

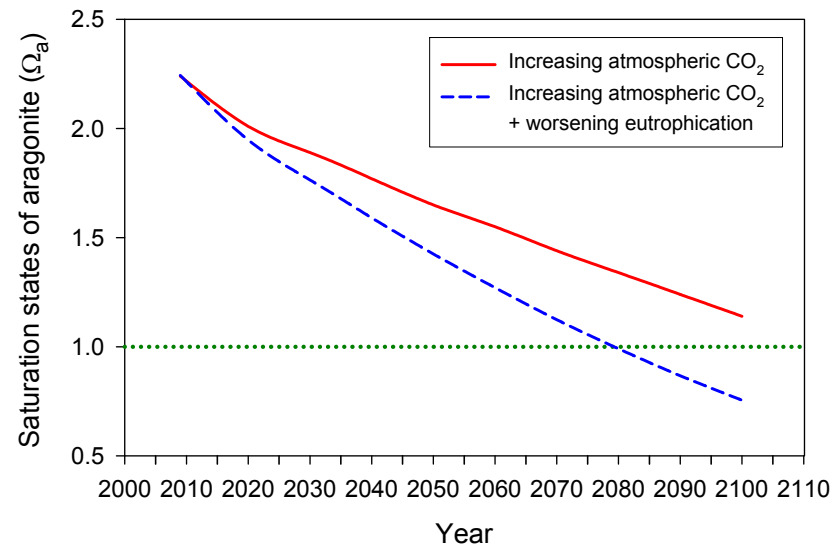

Fig. 12. The predicted time course of $\Omega_{\mathrm{a}}$ changes in the bottom water of the Changjiang plume area within the 21 st century due to (i) atmospheric $\mathrm{CO}_{2}$ increase (IPCC IS92a scenario; solid line), and (ii) the combined effect of atmospheric $\mathrm{CO}_{2}$ increase and worsening eutrophication (dashed line).

\section{Summary and concluding remarks}

Despite the fact that nearly all of the world's large rivers have $\Omega$ lower than receiving ocean waters, our observations have shown that the highest $\Omega$ values in the water column on the ECS shelf occurred in the Changjiang plume, which is featured by the lowest salinity, suggesting that the enhanced biological production fueled by the nutrient discharge from the Changjiang overwhelmed the dilution effect of freshwater on regulating $\Omega$ variations during the study period. This result implies that mixing with river runoff may not necessarily decrease the carbonate mineral saturation states in surface waters of the continental shelf. For rivers with high TA and high eutrophication (e.g., the Changjiang), the biological effect may surpass the dilution effect so that riverine discharge tends to increase $\Omega$ in the receiving seawater, while for those with low TA and less eutrophication (e.g., the Amazon), it favors decreasing $\Omega$. On the other hand, the elevated biological production in the surface layer of the Changjiang plume area may also result in a large export of organic carbon. Remineralization of organic matter back to $\mathrm{CO}_{2}$ would suppress $\Omega$ at depth, thereby driving $\Omega$ values to their minima in the bottom water of the Changjiang plume area, in particular during the summertime when stratification is strong.

Under the IS92a scenario for $\mathrm{CO}_{2}$ emissions and the assumption of air-sea equilibrium, our projection reveals that $\Omega_{\mathrm{a}}$ in surface waters would decline by $40-50 \%$ by the end of this century (decreasing from $3.5 \pm 0.4$ to $1.8 \pm 0.2$ in spring and from $3.7 \pm 0.6$ to $2.2 \pm 0.2$ in summer) due to absorption of anthropogenic $\mathrm{CO}_{2}$. For the average bottom water of the Changjiang plume area in summer, this simulation shows that the cumulative absorption of atmospheric $\mathrm{CO}_{2}$ may result in $\Omega_{\mathrm{a}}$ decreasing by $45 \%$ (from 2.2 to 1.2 ). In other words, if only the increase of atmospheric $\mathrm{CO}_{2}$ is considered, both the 
surface and bottom waters on the ECS shelf would remain supersaturated with respect to two important biologically relevant carbonate minerals (i.e., aragonite and calcite) until the end of this century. However, superimposed on such $\Omega$ decrease is the increasing eutrophication that would enhance both the photosynthetic removal of $\mathrm{CO}_{2}$ in surface waters and the respiratory release of $\mathrm{CO}_{2}$ in bottom waters, thus acting to alleviate or aggravate $\Omega$ suppression caused by the absorption of anthropogenic $\mathrm{CO}_{2}$ in surface and bottom waters, respectively. Our simulation predicts that the combination of atmospheric $\mathrm{CO}_{2}$ increase and worsening eutrophication may synergistically push the bottom water in the Changjiang plume area towards undersaturation with respect to aragonite by the end of this century (the projected $\Omega_{\mathrm{a}}$ in 2100 is about 0.8 ), which could have profound impacts on calcifying organisms in the benthic ecosystem of the Changjiang plume area. Consequently, we suggest that increasing atmospheric $\mathrm{CO}_{2}$ in conjunction with worsening eutrophication may leave the benthic ecosystem in the eutrophic coastal zone particularly susceptible to ocean acidification, which thus should be considered as one of the priority regions for further research on ocean acidification.

Acknowledgements. We are grateful to the crew of R/V Ocean Researcher I for shipboard operation and water sampling, and to C. Y. Yang, Y. H. Tsai and M. S. Li for laboratory assistance. We thank the Editor C. Rabouille and two anonymous reviewers for their critical comments that helped to improve the quality of this work. This work was supported by the National Science Council of the Republic of China (grant no. NSC 101-2611-M-019-008-MY3) and the Center of Excellence for the Oceans of the National Taiwan Ocean University.

Edited by: C. Rabouille

\section{References}

Bates, N. R., Mathis, J. T., and Cooper, L. W.: Ocean acidification and biologically induced seasonality of carbonate mineral saturation states in the Arctic Ocean, J. Geophys. Res., 114, C11007, doi:10.1029/2008JC004862, 2009.

Beardsley, R. C., Limeburner, R., Yu, H., and Cannon, G. A.: Discharge of the Changjiang (Yangtze River) into the East China Sea, Cont. Shelf Res., 4, 57-76, doi:10.1016/02784343(85)90022-6, 1985.

Borges, A. V. and Gypens, N.: Carbonate chemistry in the coastal zone responds more strongly to eutrophication than to ocean acidification, Limnol. Oceanogr., 55, 346-353, 2010.

Cai, W.-J. and Wang, Y.: The chemistry, fluxes and sources of carbon dioxide in the estuarine waters of the Satilla and Altamaha Rivers, Georgia, Limnol. Oceanogr., 43, 657-668, 1998.

Cai, W.-J., Guo, X. Chen, C.-T. A., Dai, M., Zhang, L., Zhai, W., Lohrenz, S. E., Yin, K., Harrison, P. J., and Wang, Y.: A comparative overview of weathering intensity and $\mathrm{HCO}_{3}^{-}$flux in the world's major rivers with emphasis on the Changjiang, Huanghe,
Zhujiang (Pearl) and Mississippi Rivers, Cont. Shelf Res., 28, 1538-1549, doi:10.1016/j.csr.2007.10.014, 2008.

Cai, W.-J., Hu, X., Huang, W.-J., Jiang, L.-Q., Wang, Y., Peng, T.-H., and Zhang, X.: Alkalinity distribution in the western North Atlantic Ocean margins, J. Geophys. Res., 115, C08014, doi:10.1029/2009JC005482, 2010.

Cai, W.-J., Hu, X., Huang, W.-J., Murrell, M.C., Lehrter, J.C., Lohrenz, S.E., Chou, W.-C., Zhai, W., Hollibaugh, J. T., Wang, Y., Zhao, P., Guo, X., Gundersen, K., Dai, M., and Gong, G.-C.: Acidification of subsurface coastal waters enhanced by eutrophication, Nat. Geosci., 4, 766-770, doi:10.1038/NGEO1297, 2011.

Caldeira, K. and Wickett, M. E.: Ocean model predictions of chemistry changes from carbon dioxide emissions to the atmosphere and ocean, J. Geophys. Res.-Oceans, 110, C09S04, doi:10.1029/2004JC002671, 2005.

Chen, Z., Li, J.-F., Shen, H.-T., and Wang, Z.-H.: Yangtze River of China: historical analysis of discharge variability and sediment flux, Geomorphology, 41, 77-91, 2001.

Chou, W.-C., Gong, G.-C., Sheu, D.-D., Hung, C.-C., and Tseng, T.-F.: The surface distributions of carbon chemistry parameters in the East China Sea in summer 2007, J. Geophys. Res., 114, C07026, doi:10.1029/2008JC005128, 2009a.

Chou, W.-C., Gong, G.-C., Sheu, D.-D., Jen, S., Hung, C.-C., and Chen, C.-C.: Reconciling the paradox that the heterotrophic waters of the East China Sea shelf act as a significant $\mathrm{CO}_{2}$ sink during the summertime: Evidence and implications, Geophys. Res. Lett., 36, L15607, doi:10.1029/2009GL038475, 2009 b.

Chou, W.-C., Gong, G.-C., Tseng, C.-M., Sheu, D.-D., Hung, C.-C., Chang, L.-P., and Wang, L.-W.: The carbonate system in the East China Sea in winter, Mar. Chem., 123, 44-55, 2011.

Chou, W.-C., Gong, G.-C., Cai, W.-J., and Tseng, C.-M.: Seasonality of $\mathrm{CO}_{2}$ in coastal oceans altered by increasing anthropogenic nutrient delivery from large rivers: evidence from the Changjiang-East China Sea system, Biogeosciences, 10, 38893899, doi:10.5194/bg-10-3889-2013, 2013.

Dickson, A. G.: Standard potential of the reaction: $\mathrm{AgCl}_{(\mathrm{s})}+1 / 2 \mathrm{H}_{2(\mathrm{~g})}=\mathrm{Ag}_{(\mathrm{s})}+\mathrm{HCl}_{(\mathrm{aq})}$, and the standard acidity constant of the ion $\mathrm{HSO}_{4}^{-}$in synthetic seawater from 273.15 to $318.15 \mathrm{~K}$, J. Chem. Thermodyn., 22, 113-127, doi:10.1016/0021-9614(90)90074-Z, 1990.

Dickson, A. G. and Millero, F. J.: A comparison of the equilibrium constants for the dissociation of carbonic acid in seawater media, Deep-Sea Res., 34, 1733-1743, doi:10.1016/01980149(87)90021-5, 1987.

Doney, S. C.: The growing human footprint on coastal and open-ocean biogeochemistry, Science, 328, 1512-1516, doi:10.1126/science.1185198, 2010.

Doney, S. C., Mahowald, N., Lima, I., Feely, R. A., Mackenzie, F. T., Lamarque, J.-F., and Rasch, P. J.: Impact of anthropogenic atmospheric nitrogen and sulfur deposition on ocean acidification and the inorganic carbon system, P. Natl. Acad. Sci. USA, 104, 14580-14585, 2007.

Doney, S. C., Fabry, V. J., Feely, R. A., and Kleypas, J. A.: Ocean acidification: The other $\mathrm{CO}_{2}$ problem, Annu. Rev. Mar. Sci., 1, 169-192, 2009.

Fabry, V. J., Seibel, B. A., Feely, R. A., and Orr, J. C.: Impacts of ocean acidification on marine fauna and ecosystem processes, ICES J. Mar. Sci., 65, 414-432, doi:10.1093/icesjms/fsn048, 2008. 
Fabry, V. J., McClintock, J. B., Mathis, J. T., and Grebmeier, J. M.: Ocean acidification at high latitudes: The bellwether, Oceanography, 22, 160-171, 2009.

Feely, R. A., Sabine, C. L, Lee, K., Berelson, W., Kleypas, J., Fabry, V. J., and Millero, F. J.: Impact of anthropogenic $\mathrm{CO}_{2}$ on the $\mathrm{CaCO}_{3}$ system in the oceans, Science, 305, 362-366, doi:10.1126/science.1097329, 2004.

Feely, R. A., Sabine, C. L., Hernandez-Ayon, J. M., Ianson, D., and Hales, B.: Evidence for upwelling of corrosive "acidified" water onto the continental shelf, Science, 320, 1490-1492, doi:10.1126/science.1155676, 2008.

Feely, R. A., Doney, S. C., and Cooley, S. R.: Ocean acidification: Present conditions and future changes in a high- $\mathrm{CO}_{2}$ world, Oceanography, 22, 36-47, 2009.

Gattuso, J. P., Frankignoulle, M., Bourge, I., Romaine, S., and Buddemeier, R. W.: Effect of calcium carbonate saturation of seawater on coral calcification, Glob. Planet. Change, 18, 37-46, 1998.

Gazeau, F., Quiblier, C., Jansen, J. M., Gattuso, J.-P., Middelburg, J. J., and Heip, C. H. R.: Impact of elevated $\mathrm{CO}_{2}$ on shellfish calcification, Geophys. Res. Lett., 34, L07603, doi:10.1029/2006GL028554, 2007.

Gong, G.-C., Chen, Y.-L. L., and Liu, K.-K.: Chemical hydrography and chlorophyll a distribution in the East China Sea in summer: Implications in nutrient dynamics, Cont. Shelf Res., 16, 15611590, doi:10.1016/0278-4343(96)00005-2, 1996.

Gong, G.-C., Liu, K.-K., Chiang, K.-P., Hsiung, T.-M., Chang, J., Chen, C.-C., Hung, C.-C., Chou, W.-C., Chung, C.-C., Chen, H.Y., Shiah, F.-K., Tsai, A.-Y., Hsieh, C.-H., Shiao, J.-C., Tseng, C.-M., Hsu, S.-C., Lee, H.-J., Lee, M.-A., Lin, I.-I., and Tsai, F.: Yangtze River floods enhance coastal ocean phytoplankton biomass and potential fish production, Geophys. Res. Lett., 38, L13603, doi:10.1029/2011GL047519, 2011.

Hung, C.-C., Gong, G.-C., Chiang, K.-P., Chen, H.-Y., and Yeager, K. M.: Particulate carbohydrates and uronic acids in the northern East China Sea, Estuar. Coast. Shelf Sc., 84, 565-572, 2009.

Hung, C.-C., Gong, G.-C., Chou, W.-C., Chung, C.-C., Lee, M.A., Chang, Y., Chen, H.-Y., Huang, S.-J., Yang, Y., Yang, W.R., Chung, W.-C., Li, S.-L., and Laws, E.: The effect of typhoon on particulate organic carbon flux in the southern East China Sea, Biogeosciences, 7, 3007-3018, doi:10.5194/bg-73007-2010, 2010.

Hung, C.-C., Tseng, C.-W., Gong, G.-C., Chen, K.-S., Chen, M.H., and Hsu, S.-C.: Fluxes of particle organic carbon in the East China Sea, Biogeosciences, 10, doi:10.5194/bg-10-1-2013, 2013.

Iseki, K., Okamura, K., and Kiyomoto, Y.: Seasonality and composition of downward particulate fluxes at the continental shelf and Okinawa Trough in the East China Sea, Deep-Sea Res. Pt. II, 50, 457-473, 2003.

Jiang, L.-Q., Cai, W.-J., Feely, R. A., Wang, Y., Guo, X., Gledhill, D. K., Hu, X., Arzayus, F., Chen, F., Hartmann, J., and Zhang, L.: Carbonate mineral saturation states along the U.S. East Coast, Limnol. Oceanogr., 55, 2424-2432, 2010.

Kleypas, J. A., Buddemeier, R. W., Archer, D., Gattuso, J.-P., Langdon, C., and Opdyke, B. N.: Geochemical consequences of increased atmospheric carbon dioxide on coral reefs, Science, 284, 118-120, 1999.
Kroeker, K. J., Kordas, R. L., Crim, R. N., and Singh, G. G.: Metaanalysis reveals negative yet variable effects of ocean acidification on marine organisms, Ecol. Lett., 13, 1419-1434, 2010.

Le Quéré, C., Raupach, M. R., Canadell, J. G., Marland, G., Bopp, L., Ciais, P., Conway, T. J., Doney, S. C., Feely, R. A., Foster, P., Friedlingstein, P., Gurney, K., Houghton, R. A., House, J. I., Huntingford, C., Levy, P. E., Lomas, M. R., Majkut, J., Metzl, N., Ometto, J. P., Peters, G. P., Colin Prentice, I., Randerson, J. T., Running, S. W., Sarmiento, J. L., Schuster, U., Sitch, S., Takahashi, T., Viovy, N., van der Werf, G. R., and Ian Woodward, F.: Trends in the sources and sinks of carbon dioxide, Nat. Geosci., 2, 831-836, doi:10.1038/ngeo1689, 2009.

Lewis, E. and Wallace, D. W. R.: Program developed for $\mathrm{CO}_{2}$ system calculations, Carbon Dioxide Information Analysis Center, Report ORNL/CDIAC-105, Oak Ridge National Laboratory, Oak Ridge, TN, USA, 1998.

Li, M., Xu, K., Watanabe, M., and Chen, Z.: Long-term variations in dissolved silicate, nitrogen, and phosphorus flux from the Yangtze River into the East China Sea and impacts on estuarine ecosystem, Mar. Environ. Res., 64, 399-408, 2007.

Liu, Z. and Gan, J.: Variability of the Kuroshio in the East China Sea derived from satellite altimetry data, Deep-Sea Res. Pt. I, 59, 25-36, doi:10.1016/j.dsr.2011.10.008, 2012.

Mathis, J. T., Cross, J. N., and Bates, N. R.: Coupling primary production and terrestrial runoff to ocean acidification and carbonate mineral suppression in the eastern Bering Sea, J. Geophys. Res., 116, C02030, doi:10.1029/2010JC006453, 2011a.

Mathis, J. T., Cross, J. N., and Bates, N. R.: The role of ocean acidification in systemic carbonate mineral suppression in the Bering Sea, Geophys. Res. Lett., 38, L19602, doi:10.1029/2011GL048884, 2011 b.

McNeil, B. I. and Matear, R. J.: Climate change feedbacks on future oceanicacidification, Tellus B, 59, 191-198, 2007.

Mehrbach, C., Culberson, C. H., Hawley, J. E., and Pytkowicz, R. M.: Measurement of the apparent dissociation constants of carbonic acid in seawater at atmospheric pressure, Limnol. Oceanogr., 18, 897-907,doi:10.4319/lo.1973.18.6.0897, 1973.

Meybeck, M.: Global chemical-weathering of surficial rocks estimated from river dissolved loads, Am. J. Sci., 287, 401-428, 1987.

Mucci, A.: The solubility of calcite and aragonite in seawater at various salinities, temperatures, and one atmosphere total pressure, Am. J. Sci., 283, 780-799, doi:10.2475/ajs.283.7.780, 1983.

Ning, X., Lin, C., Su, J., Liu, C., Hao, Q., and Le, F.: Longterm changes of dissolved oxygen, hypoxia, and the responses of the ecosystems in the East China Sea from 1975 to 1995, J. Oceanogr., 67, 59-75, doi:10.1007/s10872-011-0006-7, 2011.

Orr, J. C.: Recent and future changes in ocean carbonate chemistry, in: Ocean acidification, edited by: Gattuso, J.-P. and Hansson, L., Oxford University Press, New York, 41-66, 2011.

Orr, J. C., Fabry, V. J., Aumont, O., Bopp, L., Doney, S. C., Feely, R. A., Gnanadesikan, A., Gruber, N., Ishida, A., Joos, F., Key, R. M., Lindsay, K., Maier-Reimer, E., Matear, R., Monfray, P., Mouchet, A., Najjar, R. G., Plattner, G. K., Rodgers, K. B., Sabine, C. L., Sarmiento, J. L., Schlitzer, R., Slater, R. D., Totterdell, I. J., Weirig, M. F., Yamanaka, Y., and Yool, A.: Anthropogenic ocean acidification over the twenty-first century and its impacts on calcifying organisms, Nature, 437, 681-686, 2005. 
Peng, T.-H., Hung, J.-J., Wanninkhof, R., and Millero, F. J.: Carbon budget in the East China Sea, Tellus B, 51, 531-540, 1999.

Provoost, P., van Heuven, S., Soetaert, K., Laane, R. W. P. M., and Middelburg, J. J.: Seasonal and long-term changes in $\mathrm{pH}$ in the Dutch coastal zone, Biogeosciences, 7, 3869-3878, doi:10.5194/bg-7-3869-2010, 2010.

Rabouille, C., Conley, D. J., Dai, M., Cai, W.-J, Chen, C. T. A., Lansard, B., Green, R., Yin, K., Harrison, P. J., Dagg, M., and McKee, B.: Comparison of hypoxia among four river-dominated ocean margins: the Changjiang (Yangtze), Mississippi, Pearl, and Rhône rivers. Cont. Shelf Res., 28, 1527-1537, 2008.

Revelle, R. and Suess, H. E.: Carbon dioxide exchange between atmosphere and ocean and the question of an increase of atmospheric $\mathrm{CO}_{2}$ during the past decades, Tellus, 9, 18-27, 1957.

Ries, J. B., Cohen, A. L., and McCorkle, D. C.: Marine calcifiers exhibit mixed responses to $\mathrm{CO}_{2}$-inducedocean acidification, $\mathrm{Ge}$ ology, 34, 1131-1134, 2009.

Riley, J. P. and Tongudai, M.: The major cation/chlorinity ratios in sea water, Chem. Geol., 2, 263-269, doi:10.1016/00092541(67)90026-5, 1967.

Sabine, C. L., Heimann, M., Artaxo, P., Bakker, D. C. E., Chen, C. T. A., Field, C. B., Gruber, N., Le Quéré, C., Prinn, R. G., Richey, J. E., Lankao, P. R., Sathaye, J. A., and Valentini, R.: Current status and past trends of the global carbon cycle, in: The Global Carbon Cycle: Integrating Humans, Climate, And The Natural World, edited by: Field, C. B. and Raupach, M. R., Island Press, Washington, DC, 17-44, 2004a.

Sabine, C. L., Feely, R. A., Gruber, N., Key, R. M., Lee, K., Bullister, J. L., Wanninkhof, R., Wong, C. S., Wallace, D. W. R., Tilbrook, B., Millero, F. J., Peng, T.-H., Kozyr, A., Ono, T., and Rios, A. F.: The oceanic sink for anthropogenic $\mathrm{CO}_{2}$, Science, 305, 367-371, doi:10.1126/science.1097403, 2004b.

Salisbury, J. E., Green, M., Hunt, C., and Campbell, J.: Coastal acidification by rivers: A threat to shellfish?, EOS Transactions, 89, 513-528, 2008.

Sarmiento, J. and Gruber, N.: The ocean carbon cycle, in: Ocean biogeochemical dynamics, Princeton University Press, 318-358, 2006.

Seitzinger, S. P., Kroeze, C., Bouwman, A. F., Caraco, N., Dentener, F., and Styles, R. V.: Global patterns of dissolved inorganic and particulate nitrogen inputs to coastal systems: recent conditions and future projections, Estuaries, 25, 640-655, 2002.
Seitzinger, S. P., Mayorga, E., Bouwman, A. F., Kroeze, C., Beusen, A. H. W., Billen, G., Van Drecht, G., Dumont, E., Fekete, B. M., Garnier, J., and Harrison, J. A.: Global river nutrient export: A scenario analysis of past and future trends, Global Biogeochem. Cy., 24, GB0A08, doi:10.1029/2009GB003587, 2010.

Shim, J., Kim, D., Kang, Y. C., Lee, J. H., Jang, S. T., and Kim, C. H.: Seasonal variations in $p \mathrm{CO}_{2}$ and its controlling factors in surface seawater of the northern East China Sea, Cont. Shelf Res., 27, 2623-2636, 2007.

Tsunogai, S., Watanabe, S., and Sato, T.: Is there a "continental shelf pump" for the absorption of atmospheric $\mathrm{CO}_{2}$, Tellus B, 51, 701712, 1999.

Wang, B: Cultural eutrophication in the Changjiang (Yangtze River) plume: History and perspective, Estuar. Coast. Shelf Sc., 69, 471-477, doi:10.1016/j.ecss.2006.05.010, 2006.

Wang, S.-L., Chen, C.-T. A., Hong, G.-H., and Chung, C.-S.: Carbon dioxide and related parameters in the East China Sea, Cont. Shelf Res., 20, 525-544, 2000.

Yamamoto-Kawai, M., McLaughlin, F. A., and Carmack, E. C.: Effects of ocean acidification, warming and melting of sea ice on aragonite saturation of the Canada Basin surface water, Geophys. Res. Lett., 38, L03601, doi:10.1029/2010GL045501, 2011.

Yan, W., Mayorga, E., Li, X., Seitzinger, S. P., and Bouwman, A. F.: Increasing anthropogenic nitrogen inputs and riverine DIN exports from the Changjiang River basin under changing human pressures, Global Biogeochem. Cy., 24, GB0A06, doi:10.1029/2009GB003575, 2010.

Zeebe, R. and Wolf-Gladrow, D.: $\mathrm{CO}_{2}$ in Seawater: Equilibrium, Kinetics, Isotopes, Elsevier Oceanography Series, 65, Elsevier, New York, 2001.

Zhai, W. and Dai, M.: On the seasonal variation of air-sea $\mathrm{CO}_{2}$ fluxes in the outer Changjiang (Yangtze River) Estuary East China Sea, Mar. Chem., 117, 2-10, 2009.

Zhang, J., Liu, S. M., Ren, J. L., Wu, Y., and Zhang, G. L.: Nutrient gradients from the eutrophic Changjiang (Yangtze River) Estuary to the oligotrophic Kuroshio waters and re-evaluation of budgets for the East China Sea Shelf, Prog. Oceanogr., 74, 449478, 2007. 